\title{
TU/e EnNHOUN

\section{The chemistry and energetics of the interface between metal halide perovskite and atomic layer deposited metal oxides}

\section{Citation for published version (APA):}

Bracesco, A., Burgess, C. H., Todinova, A., Zardetto, V., Koushik, D., Kessels, W. M. M., Dogan, I., Weijtens, C. H. L., Veenstra, S. C., Andriessen, H. A. J. M., \& Creatore, M. (2020). The chemistry and energetics of the interface between metal halide perovskite and atomic layer deposited metal oxides. Journal of Vacuum Science and Technology A: Vacuum, Surfaces, and Films, 38(6), [063206]. https://doi.org/10.1116/6.0000447

\section{Document license: \\ TAVERNE}

DOI:

10.1116/6.0000447

Document status and date:

Published: 01/12/2020

\section{Document Version:}

Publisher's PDF, also known as Version of Record (includes final page, issue and volume numbers)

\section{Please check the document version of this publication:}

- A submitted manuscript is the version of the article upon submission and before peer-review. There can be important differences between the submitted version and the official published version of record. People interested in the research are advised to contact the author for the final version of the publication, or visit the $\mathrm{DOI}$ to the publisher's website.

- The final author version and the galley proof are versions of the publication after peer review.

- The final published version features the final layout of the paper including the volume, issue and page numbers.

Link to publication

\section{General rights}

Copyright and moral rights for the publications made accessible in the public portal are retained by the authors and/or other copyright owners and it is a condition of accessing publications that users recognise and abide by the legal requirements associated with these rights.

- Users may download and print one copy of any publication from the public portal for the purpose of private study or research.

- You may not further distribute the material or use it for any profit-making activity or commercial gain

- You may freely distribute the URL identifying the publication in the public portal.

If the publication is distributed under the terms of Article 25fa of the Dutch Copyright Act, indicated by the "Taverne" license above, please follow below link for the End User Agreement:

www.tue.nl/taverne

Take down policy

If you believe that this document breaches copyright please contact us at:

openaccess@tue.nl

providing details and we will investigate your claim. 


\section{The chemistry and energetics of the}

\section{interface between metal halide perovskite and atomic layer deposited metal oxides ${ }^{\circ}$}

Cite as: J. Vac. Sci. Technol. A 38, 063206 (2020); https://doi.org/10.1116/6.0000447

Submitted: 09 July 2020 . Accepted: 16 September 2020 . Published Online: 07 October 2020

(D) Andrea E. A. Bracesco, Claire H. Burgess, Anna Todinova, Valerio Zardetto, (D) Dibyashree Koushik, (D) Wilhelmus M. M (Erwin) Kessels, (D) Ilker Dogan, (D) Christ H. L. Weijtens, Sjoerd Veenstra, Ronn Andriessen, and (iD) Mariadriana Creatore

\section{COLLECTIONS}

Paper published as part of the special topic on 30 years of the Nellie Yeoh Whetten Award - Celebrating the Women of the AVS

F This paper was selected as Featured
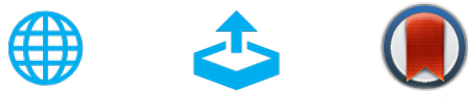

\section{ARTICLES YOU MAY BE INTERESTED IN}

Consistency and reproducibility in atomic layer deposition

Journal of Vacuum Science \& Technology A 38, 020804 (2020); https://

doi.org/10.1116/1.5140603

\section{Detailed Balance Limit of Efficiency of p-n Junction Solar Cells}

Journal of Applied Physics 32, 510 (1961); https://doi.org/10.1063/1.1736034

tert-butoxides as precursors for atomic layer deposition of alkali metal containing thin films

Journal of Vacuum Science \& Technology A 38, 060804 (2020); https://

doi.org/10.1116/6.0000589

\section{HDDEN \\ Instruments for Advanced Science}

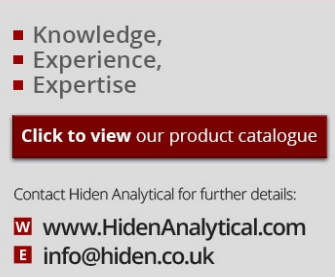

E info@hiden.co.uk
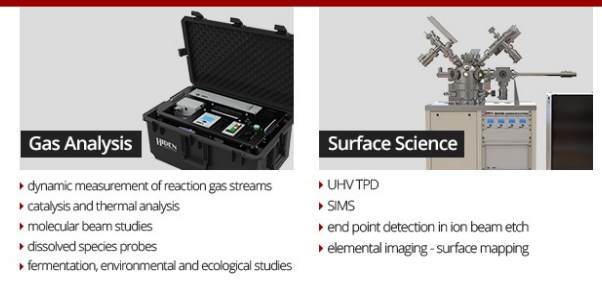

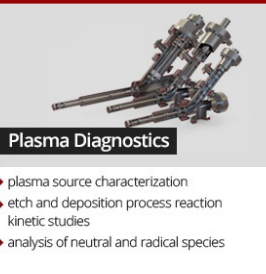

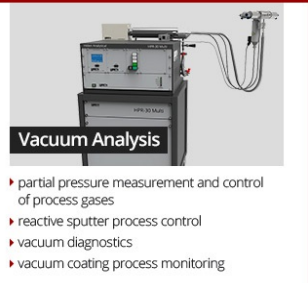




\title{
The chemistry and energetics of the interface between metal halide perovskite and atomic layer deposited metal oxides
}

Cite as: J. Vac. Sci. Technol. A 38, 063206 (2020); doi: $10.1116 / 6.0000447$

Submitted: 9 July 2020 - Accepted: 16 September 2020 .

Published Online: 7 October 2020

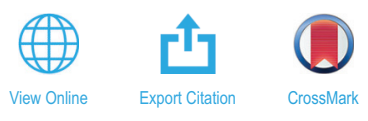

Andrea E. A. Bracesco, ${ }^{7}$ (D) Claire H. Burgess, ${ }^{7}$ Anna Todinova, ${ }^{7}$ Valerio Zardetto, ${ }^{2}$ Dibyashree Koushik, ${ }^{1}$ (D) Wilhelmus M. M (Erwin) Kessels, ${ }^{7}$ (D) Ilker Dogan, ${ }^{2}$ (D) Christ H. L. Weijtens, ${ }^{7}$ (D) Sjoerd Veenstra, ${ }^{2}$ Ronn Andriessen, ${ }^{2}$ and Mariadriana Creatore ${ }^{1, a)}$ (D)

\section{AFFILIATIONS \\ ${ }^{1}$ Department of Applied Physics, Eindhoven University of Technology (TU/e), P.O. Box 513, 5600 MB Eindhoven, The Netherlands \\ ${ }^{2} \mathrm{TNO}$, High Tech Campus 21, 5656 AE Eindhoven, The Netherlands}

Note: This paper is part of the Special Topic Collection on 30 years of the Nellie Yeoh Whetten Award - Celebrating the Women of the AVS.

a)Electronic mail: m.creatore@tue.n|

\begin{abstract}
The chemistry of the interface between the metal halide perovskite absorber and the charge transport layer affects the performance and stability of metal halide perovskite solar cells (PSCs). The literature provides several examples of poor PSC conversion efficiency values, when electron transport layers (ETLs), such as $\mathrm{SnO}_{2}$ and $\mathrm{TiO}_{2}$, are processed by atomic layer deposition (ALD) directly on the perovskite absorber. In the present work, we shed light on the chemical modifications occurring at the perovskite surface, during ALD processing of $\mathrm{SnO}_{2}$ and $\mathrm{TiO}_{2}$, in parallel with the evaluation of the PSC cell performance. The ALD processes are carried out on a $(\mathrm{Cs}, \mathrm{FA}) \mathrm{Pb}(\mathrm{I}, \mathrm{Br})_{3}$ perovskite by adopting tetrakis(dimethylamino)tin(IV) and tetrakis(dimethylamino)titanium(IV) as metal precursors and $\mathrm{H}_{2} \mathrm{O}$ as the coreactant for $\mathrm{SnO}_{2}$ and $\mathrm{TiO}_{2}$, respectively. Perovskite surface modification occurs in the form of an ultrathin $\mathrm{PbBr}_{2}$ layer. Furthermore, in the case of $\mathrm{SnO}_{2}$, halogen molecules are detected at the interface, in parallel with the initial growth of an oxygen-deficient $\mathrm{SnO}_{2}$. Subgap defect states just above the valence band maximum of $\mathrm{SnO}_{2}$ are also detected. These states act as hole traps at the perovskite/SnO $\mathrm{O}_{2}$ interface, subsequently promoting charge recombination and deteriorating the performance of the cell. We hypothesize that a redox reaction between the perovskite, or its decomposition products, and the Sn metal center of the ALD precursor takes place: $\mathrm{I}^{-}$and $\mathrm{Br}^{-}$are oxidized to $\mathrm{I}_{2}$ and $\mathrm{Br}_{2}$, respectively, and $\mathrm{Sn}(\mathrm{IV})$ is reduced to $\mathrm{Sn}(\mathrm{II})$. In contrast, the $\mathrm{Ti}(\mathrm{IV})$ metal center does not undergo any redox process, and, as a result, a promising $11 \%$ power conversion efficiency is measured with $\mathrm{TiO}_{2}$ as the ETL. This result strongly suggests that $\mathrm{TiO}_{2}$ may be a more suitable ETL, when processed directly on the perovskite absorber.
\end{abstract}

Published under license by AVS. https://doi.org/10.1116/6.0000447

\section{INTRODUCTION}

Over a relatively short period of about ten years, metal halide perovskite solar cells (PSCs) have been successful in gaining widespread attention in the photovoltaic (PV) community, with a current record efficiency of over 25\%. ${ }^{1}$ This accomplishment has been the result of both fundamental understanding of the metal halide perovskite material itself (in terms of crystal growth, chemical composition, and optoelectronic properties) ${ }^{2}$ and improved engineering of the device architecture. The latter includes novel interfacial design approaches and the development of efficient charge transport and electrode layers. ${ }^{2-4}$ In this specific case, the use of thin films processed by atomic layer deposition (ALD) has been particularly alluring, a manifestation of which is the extensive application of ALD in PSCs, which is showcased by a number of publications on this topic over the last years, ${ }^{5-14}$ starting from $2014 .{ }^{15}$

Inherently conformal and pinhole-free films processed by ALD have been applied either as electron transport layers (ETLs) in an " $n-i-p$ " solar cell configuration or as hole transport layers (HTLs) in a "p-i-n" solar cell configuration, 9,11 where " $n$ " 
corresponds to the ETL, "i" to the intrinsic perovskite absorber, and " $p$ " to the HTL. In addition, these films, when applied on top of perovskites in combination with an organic charge transport interlayer (CTL) (such as [6,6]-phenyl- $\mathrm{C}_{61}$-butyric acid methyl ester, $\mathrm{PCBM}$, or $\mathrm{C}_{60}$ ) in a $\mathrm{p}-\mathrm{i}-\mathrm{n}$ configuration, have been shown to provide several improvements ${ }^{7}$ These are good charge extraction, reduced potential damage to the sensitive underlying layers during sputtering of the transparent top electrode, and excellent barrier properties against moisture and thermal stress. This has enabled the engineering of highly efficient and environmentally stable perovskite-based single-junction and tandem devices. ${ }^{6,7,14-20}$

At the same time, the presence of organic ETLs in p-i-n cells may in some cases introduce parasitic absorption losses and potential shunting pathways, especially when large area devices are fabricated. ${ }^{21}$ In addition, PSCs that contain organic ETLs have generally exhibited very poor mechanical properties. ${ }^{22}$ Therefore, recently, there has been widespread interest in the application of inorganic ETLs processed by ALD directly on top of the perovskite absorber, i.e., without the addition of organic interlayers. However, to date, the achieved power conversion efficiencies (PCEs) in this device configuration fall between $0.5 \%$ and $8.2 \%$ (Table I). ${ }^{8,10}$ The underlying reasons are not very clear yet. A contributing factor is expected to be the chemical modification that occurs at the surface (or even bulk) of the perovskite during ALD processing directly on top of the perovskite.

Progress has already been made in this field. For example, several studies have focused on the chemical modifications occurring in the perovskite upon direct growth of $\mathrm{Al}_{2} \mathrm{O}_{3}$ on top of the perovskite. So far, $\mathrm{Al}_{2} \mathrm{O}_{3}$ is considered the only successful case of direct ALD processing on the perovskite absorber. ${ }^{12,23-25}$ A recent work from our group using infrared (IR) and x-ray photoelectron spectroscopy (XPS) analysis revealed that the interaction between $\mathrm{H}_{2} \mathrm{O}$ (used as coreactant) and $\mathrm{CH}_{3} \mathrm{NH}_{3} \mathrm{PbI}_{3-\mathrm{x}} \mathrm{Cl}_{\mathrm{x}}$ was negligible under the conditions adopted in the ALD recipe. ${ }^{26}$ On the contrary, exposure to trimethylaluminum (TMA, used as metal precursor) was found to degrade the perovskite surface, leading to the effusion of methylammonium (MA) cations. ${ }^{26,27}$ In parallel, it was shown that TMA and $\mathrm{H}_{2} \mathrm{O}$ do not diffuse into the bulk of the perovskite. $^{26-28}$ Furthermore, by means of in situ quartz crystal microbalance (QCM) and IR spectroscopy, it was shown that the TMA molecules etch the $\mathrm{CH}_{3} \mathrm{NH}_{3} \mathrm{PbI}_{3-\mathrm{x}} \mathrm{Cl}_{\mathrm{x}}$ perovskite surface at $75^{\circ} \mathrm{C} .{ }^{27}$ A similar behavior was reported by Yu et al. ${ }^{29}$ Synchrotron
XPS analysis was employed by Kot et al., ${ }^{30}$ which indicated that the interaction of ALD precursors occurs only at the surface of the $\mathrm{CH}_{3} \mathrm{NH}_{3} \mathrm{PbI}_{3}$ and $\mathrm{FA}_{0.85} \mathrm{MA}_{0.15} \mathrm{~Pb}\left(\mathrm{Br}_{0.15} \mathrm{I}_{0.85}\right)_{3}$ perovskite (where $\mathrm{FA}$ corresponds to the formamidinium cation) during the growth of $\mathrm{Al}_{2} \mathrm{O}_{3}$ at room temperature. ${ }^{23,24}$ In parallel, they showed that there is covalent bonding at the $\mathrm{CH}_{3} \mathrm{NH}_{3} \mathrm{PbI}_{3} / \mathrm{Al}_{2} \mathrm{O}_{3}$ interface. At the same time, they identified a charge balance between the polaronic and excitonic states in $\mathrm{CH}_{3} \mathrm{NH}_{3} \mathrm{PbI}_{3}$ and $\mathrm{Al}_{2} \mathrm{O}_{3}{ }^{23}$

In the case of ETLs, the chemistry of the metalorganic precursor plays a critical role. ${ }^{5,8,10}$ For ZnO, the diethyl-Zn (DEZ) precursor strongly reacted with the organic component of the hybrid perovskite leading to its complete decomposition. This was witnessed for both $\mathrm{CH}_{3} \mathrm{NH}_{3} \mathrm{PbI}_{3}$ and (MA,FA) $\mathrm{Pb}(\mathrm{I}, \mathrm{Br})_{3}$-based perovskite systems. ${ }^{8,10}$ Moreover, even after 100 cycles, no growth of $\mathrm{ZnO}$ was detected on the $\mathrm{CH}_{3} \mathrm{NH}_{3} \mathrm{PbI}_{3}$ perovskite. ${ }^{8} \mathrm{Yu}$ et $\mathrm{al}^{31}$ investigated the nucleation of $\mathrm{ZnO}$ on top of the $\mathrm{CH}_{3} \mathrm{NH}_{3} \mathrm{PbI}_{3} / \mathrm{PCBM}$ layer. By performing IR and QCM analyses, they showed that $\mathrm{ZnO}$ did not readily grow even on top of PCBM. However, the PCBM blocked the DEZ precursor from abstracting the organic cation of the perovskite. In contrast to DEZ, they observed that TMA could readily react with the carbonyl group of PCBM. Therefore, they employed $\mathrm{Al}_{2} \mathrm{O}_{3}$ as a seeding layer on top of PCBM coated $\mathrm{CH}_{3} \mathrm{NH}_{3} \mathrm{PbI}_{3}$ in order to achieve the nucleation of $\mathrm{ZnO}$.

Another metal oxide that has been adopted as a potential ETL is $\mathrm{TiO}_{2}$, although always in combination with a PCBM or C60 interlayer. ${ }^{7,20,32-35}$ The ALD process involved the application of tetrakis(dimethylamino)titanium(IV) (TDMA-Ti) and $\mathrm{H}_{2} \mathrm{O}$, as the metalorganic precursor and coreactant, respectively. Despite these promising results in combination with organic interlayers, to the best of our knowledge, $\mathrm{TiO}_{2}$ grown directly on top of the absorber has not been used as sole ETL. Thus, the perovskite $/ \mathrm{TiO}_{2}$ interface has been so far a limited subject of investigation. ${ }^{33,35,36}$

Among all ETLs grown directly on perovskites, $\mathrm{SnO}_{2}$ is the most investigated. Palmstrom et al. ${ }^{10}$ adopted tetrakis(dimethylamino)tin(IV) (TDMA-Sn) as the metal precursor for $\mathrm{SnO}_{2}$ and identified that effusion of the FA cation from the $\mathrm{Cs}_{0.17} \mathrm{FA}_{0.83} \mathrm{~Pb}$ $\left(\mathrm{Br}_{0.17} \mathrm{I}_{0.83}\right)_{3}$ perovskite occurs at temperatures of $100^{\circ} \mathrm{C}$ and above during the ALD process. With regard to the thermal stability of the perovskite, the authors reported the formation of crystalline $\mathrm{PbI}_{2}$ upon vacuum annealing of the perovskite at $150^{\circ} \mathrm{C}$, which is in

TABLE I. PV parameters of p-i-n PSCs with $\mathrm{SnO}_{2}$ and $\mathrm{TiO}_{2}$ serving as ETLs directly grown on the perovskite: data from the literature and values from this work. PV parameters are reported for reverse scan only. All metal oxide films were grown using $\mathrm{H}_{2} \mathrm{O}$ as the coreactant. TDMA-Sn and TDMA-Ti precursors were used for $\mathrm{SnO}_{2}$ and $\mathrm{TiO}_{2}$, respectively. The first column refers to the perovskite composition: (1) $\mathrm{FA}_{0.83} \mathrm{MA}_{0.17} \mathrm{~Pb}\left(\mathrm{I}_{0.83} \mathrm{Br}_{0.17}\right)_{3} ;$ (2) $\mathrm{Cs}_{0.17} \mathrm{FA}_{0.83} \mathrm{~Pb}\left(\mathrm{I}_{0.5} \mathrm{Br}_{0.5}\right)_{3} ;$ (3) $\left.\mathrm{Cs}_{0.17} \mathrm{FA}_{0.83} \mathrm{~Pb} \mathrm{I}_{0.83} \mathrm{Br}_{0.17}\right)_{3} ;$ (4) and (5) $\mathrm{Cs}_{0.15} \mathrm{FA}_{0.85} \mathrm{~Pb}\left(\mathrm{l}_{0.92} \mathrm{Br}_{0.08}\right)_{3}$.

\begin{tabular}{|c|c|c|c|c|c|c|c|}
\hline & $\begin{array}{c}\text { Growth T } \\
\left({ }^{\circ} \mathrm{C}\right)\end{array}$ & PSC architecture & $\begin{array}{l}\mathrm{V}_{\mathrm{OC}} \\
(\mathrm{V})\end{array}$ & $\begin{array}{c}\mathrm{J}_{\mathrm{SC}} \\
\left(\mathrm{mA} / \mathrm{cm}^{2}\right)\end{array}$ & $\mathrm{FF}$ & $\begin{array}{c}\text { PCE } \\
(\%)\end{array}$ & Reference \\
\hline 1 & 120 & $\mathrm{NiO}_{\mathrm{x}} /$ perovskite $/ \mathrm{SnO}_{2} / \mathrm{Au}$ & 0.48 & 19.0 & 43 & 4.0 & 8 \\
\hline 2 & 100 & $\mathrm{NiO}_{\mathrm{x}} /$ perovskite/SnO${ }_{2} / \mathrm{ZTO} / \mathrm{Au}$ & 0.97 & 15.9 & 53.4 & 8.2 & 10 \\
\hline 3 & 80 & $\mathrm{NiO}_{\mathrm{x}} /$ perovskite $/ \mathrm{SnO}_{2} / \mathrm{ITO} / \mathrm{Ag}$ & 0.73 & 2.9 & 24.5 & 0.5 & 10 \\
\hline 4 & 100 & PTAA/perovskite/ $\mathrm{SnO}_{2} / \mathrm{Al}$ & 0.90 & 15.1 & 43 & 5.9 & This work \\
\hline 5 & 100 & PTAA/perovskite/ $/ \mathrm{TiO}_{2} / \mathrm{Al}$ & 0.92 & 19.8 & 75 & 13.6 & This work \\
\hline
\end{tabular}


line with the findings from Kot et al. ${ }^{37}$ On the contrary, Hultqvist et al. ${ }^{8}$ reported no detrimental effect on the bulk or surface stability [by employing $\mathrm{x}$-ray diffraction (XRD) and XPS, respectively] of an $(\mathrm{MA}, \mathrm{FA}) \mathrm{Pb}(\mathrm{I}, \mathrm{Br})_{3}$ perovskite when exposed to TDMA-Sn within a temperature window of $85-150^{\circ} \mathrm{C}$. From XPS depth profile analysis, they suggested the possibility of halogen incorporation into the $\mathrm{SnO}_{2}$ film in the early growth stage.

Both works, despite reporting contrasting results in terms of chemical modifications during ALD, showed that limited solar cell performances were achieved upon direct ALD processing on perovskites. Hultqvist et al. reported a PCE of 3.4\%, which was raised to $7.8 \%$ after performing biasing treatments on the cells (Table I). ${ }^{8}$ Palmstrom et al. investigated different $\mathrm{SnO}_{2}$ deposition parameters and two perovskite compositions in their devices, leading to a limited cell efficiency of $8.2 \%$ (Table I). ${ }^{10}$ Both studies cited energy barriers as potential issues in their cells: band diagrams, constructed partially from literature data, showed a potential conduction band maximum (CBM) misalignment at the perovskite $/ \mathrm{SnO}_{2}$ interface. ${ }^{8,10}$ However, it should be noted that a favorable energy level alignment is not the only condition to be fulfilled. Often, interface defects, ${ }^{38}$ responsible for nonradiative charge recombination, can severely affect the cell performance. In this respect, the role of PCBM is to serve as an ETL and a passivation layer for trap states at the interface between the perovskite and the metal oxide. ${ }^{39}$ All the above-mentioned studies related to the processing of $\mathrm{SnO}_{2}$ directly on top of the perovskite have laid the groundwork for understanding the perovskite/ETL systems. Moreover, they strongly suggest that the factors contributing to poor PSC performance are not yet fully understood and need further investigation. With the present contribution, we aim to systematically elucidate the chemical changes occurring in the bulk and surface of hybrid perovskite substrates upon ALD processing of ETLs, such as $\mathrm{SnO}_{2}$ and $\mathrm{TiO}_{2}$ using metalorganic precursors with the same ligand chemistry, TDMA-Sn and TDMA-Ti, and $\mathrm{H}_{2} \mathrm{O}$ as the coreactant. Concurrently, we aim to identify the effect of these changes on the energetics of the perovskite/metal oxide systems and on the cell performance. We select a $\mathrm{Cs}_{0.15} \mathrm{FA}_{0.85} \mathrm{~Pb}\left(\mathrm{I}_{0.92} \mathrm{Br}_{0.08}\right)_{3}$ perovskite, because of its wide application in several literature studies, which also involved $\mathrm{SnO}_{2}$ and $\mathrm{TiO}_{2}$ as ETLs. We begin our work by comparing the cell performance with the employed metal oxide ETLs. Next, we identify the chemical changes that the perovskite absorber undergoes upon ALD processing by means of XPS. The latter is also adopted to determine the chemical composition of extremely thin $\mathrm{SnO}_{2}$ and $\mathrm{TiO}_{2}$ films. Finally, the energetics of the perovskite/ metal oxide systems are estimated using ultraviolet photoelectron spectroscopy (UPS).

We found that the growth of $\mathrm{SnO}_{2}$ and $\mathrm{TiO}_{2}$ does not affect the bulk of the metal halide perovskite and only a thin interfacial $\mathrm{PbBr}_{2}$ layer is formed. Despite the similar chemistry of the selected ALD precursors, we show that in the case of perovskite/ $\mathrm{SnO}_{2}$, we detect the formation of $\mathrm{Br}_{2}$ and $\mathrm{I}_{2}$, in the proximity of the perovskite $/ \mathrm{SnO}_{2}$ interface. Along with that, the initial growth of $\mathrm{SnO}_{2}$ on the perovskite is characterized by the formation of an oxygendeficient film accompanied by the presence of subgap states near the valence band maximum (VBM) of $\mathrm{SnO}_{2}$, which are assigned to reduced $\mathrm{Sn}$ (II) states. We relate the presence of such defect states to a redox reaction taking place between the halide species $\mathrm{Br}^{-}$and $\mathrm{I}^{-}$ of either the perovskite or its decomposition products and the $\mathrm{Sn}(\mathrm{IV})$ metal center of the ALD precursor. The accumulation of molecular halides at the perovskite $/ \mathrm{SnO}_{2}$ interface and the growth of $\mathrm{SnO}_{2}$ that exhibits subgap defects are responsible for the compromised cell performance and s-shaped $\mathrm{J}-\mathrm{V}$ curves when $\mathrm{SnO}_{2}$ is used as the sole ETL. Instead, when $\mathrm{TiO}_{2}$ is grown directly on the perovskite, the above-mentioned redox process does not occur. As a matter of fact, cells employing $\mathrm{TiO}_{2}$ deliver efficiencies overcoming the highest values reported so far for metal oxide CTLs processed directly on top of the perovskite, with an $11 \%$ PCE deduced from maximum power point tracking (MPPT).

\section{EXPERIMENT}

\section{A. Perovskite solar cell fabrication}

The device fabrication begins with ultrasonically cleaning the patterned glass/ITO substrates (Naranjo Substrates, $13-15 \Omega / s q$ ) with soap water, de-ionized water, and isopropanol, which is followed by a UV-ozone treatment for $30 \mathrm{~min}$. The manipulations that follow are performed inside a nitrogen-filled glovebox. A poly(triarylamine) (PTAA) solution in toluene $2 \mathrm{mg} / \mathrm{ml}$ (Sigma-Aldrich) is spin coated on the glass/ITO substrates at $5000 \mathrm{rpm}$ for $30 \mathrm{~s}$ and annealed at $100^{\circ} \mathrm{C}$ for $10 \mathrm{~min}$. Afterward, the dual cation perovskite $\mathrm{Cs}_{0.15} \mathrm{FA}_{0.85} \mathrm{~Pb}\left(\mathrm{I}_{0.92} \mathrm{Br}_{0.08}\right)_{3}$ solution is prepared by mixing a $1.33 \mathrm{M}$ concentration of the following precursors: $\mathrm{PbBr}_{2}$ (99.9\%) and $\mathrm{PbI}_{2}$ (99.999\%), both from TCI; FAI (99.9\%) and FABr (99.9\%) both from Greatcell (Dyesol); and CsI (99\%, Sigma-Aldrich), in anhydrous DMF:DMSO (vol. ratio = 9:1), followed by stirring overnight at room temperature. The perovskite solution is then spin coated with a two-step procedure: at $2000 \mathrm{rpm}$ for $10 \mathrm{~s}$ and at $5000 \mathrm{rpm}$ for another $30 \mathrm{~s}$. During the second step, $300 \mu \mathrm{l}$ of chlorobenzene is poured on the spinning substrate $20 \mathrm{~s}$ prior to the end of the program. The film is then annealed on a hot plate at $100^{\circ} \mathrm{C}$ for $10 \mathrm{~min}$. For the devices employing a PCBM interlayer, a $20 \mathrm{mg} \mathrm{ml}^{-1}$ PCBM (Solenne B.V., 99\%) solution in chlorobenzene is spin coated onto the perovskite layer at $1500 \mathrm{rpm}$ for $50 \mathrm{~s}$. Next, metal oxide layers are grown either directly on the perovskite or on an overlaying PCBM film. For the reference device, a bathocuproine (BCP) solution in ethanol $(0.5 \mathrm{mg} / \mathrm{ml})$ was spin coated at $3000 \mathrm{rpm}$ for $40 \mathrm{~s}$. Afterward, $100 \mathrm{~nm}$ of $\mathrm{Cu}$ (after BCP spin-coating) or $100 \mathrm{~nm}$ of $\mathrm{Al}$ (after ALD of metal oxide layers) electrode is thermally evaporated at a pressure of $10^{-6}$ mbar. In both cases, a shadow mask was used for electrode deposition.

\section{B. Metal oxide deposition}

TDMA-Sn (99.9\%, STREM Chemicals) is used as the metalorganic precursor for the $\mathrm{SnO}_{2}$ thin film deposition and TDMA-Ti (99.9\%, STREM Chemicals) is used for $\mathrm{TiO}_{2}$. The interface analysis studies are also carried out for $\mathrm{Al}_{2} \mathrm{O}_{3}$ grown with dimethylaluminum isopropoxide (98\%, Dockweiler Chemicals) as a precursor, which delivers good performances in n-i-p cells, as we have reported previously. ${ }^{40} \mathrm{H}_{2} \mathrm{O}$ is used as the coreactant for all the ALD processes. The processes are carried out taking into account the thermal sensitivity of the perovskite absorber setting the reactor chambers and substrate tables to $100{ }^{\circ} \mathrm{C} .{ }^{10}$ The ALD reactor 
used for $\mathrm{SnO}_{2}$ and $\mathrm{Al}_{2} \mathrm{O}_{3}$ growth is OpAL, and for $\mathrm{TiO}_{2}$, Flexal2 is used (both from Oxford Instruments). The details of the ALD processes are described in detail in Sec. I in the supplementary material. $^{73}$

\section{Characterization techniques}

The structure of the pristine perovskite and the perovskite/ metal oxide layers is evaluated by XRD using a PANalytical X'Pert Pro MRD system, with $\mathrm{Cu} \mathrm{K \alpha}$ radiation $(\lambda=1.541 \AA)$ in the $2 \theta$ range of $10^{\circ}-60^{\circ}$, with a step size of $0.02^{\circ}$.

The surface composition of the metal oxides grown on crystalline silicon $(\mathrm{c}-\mathrm{Si})$ and on perovskite is investigated by means of XPS in a Thermo Scientific K-Alpha system, equipped with an $\mathrm{Al}$ $\mathrm{K} \alpha \mathrm{x}$-ray source $(1487 \mathrm{eV})$ without any presputtering for a series of samples with different metal oxide thicknesses. Using THERMO AVANTAGE software, each spectral feature is fitted with Gaussian/ Lorentzian mixed peaks, which have a fixed full width half maximum for each chemical state across all the pristine perovskite and perovskite/metal oxide samples. For each perovskite/metal oxide sample, unless specified otherwise, the binding energies (BE) of spectral features are aligned such that the perovskite I-3d $\mathrm{d}_{5 / 2}$ spectral feature occurs at $619.5 \mathrm{eV}$ (as it does in the pristine perovskite) rather than aligning to adventitious carbon for the sake of comparison of the spectra. ${ }^{41}$ Details regarding peak alignment are shown in Sec. II in the supplementary material. ${ }^{73}$ The thickness of the films grown on top of the perovskite is determined in the same manner as in a previous publication. ${ }^{26}$

UPS measurements are performed in a VG EscaLab II system (Thermo Fisher Scientific Inc.) with a base pressure of $10^{-8} \mathrm{~Pa}$, using $\mathrm{He}-\mathrm{I}$ radiation $(21.22 \mathrm{eV})$ and $-6 \mathrm{~V}$ bias. The collected information regarding the work function and ionization energy are used to obtain the Fermi level $\left(\mathrm{E}_{\mathrm{f}}\right)$ and valence band maximum positions for the pristine perovskite and perovskite/metal oxide systems.

The electrical characterization of the completed solar cells is performed under a solar simulator calibrated to AM 1.5 using a commercial c-Si reference cell (ReRa Solutions, IEC 60904-9 compliant and certified) and using a Keithley 2400 source meter to collect the current-voltage $(\mathrm{J}-\mathrm{V})$ curves. The $\mathrm{J}-\mathrm{V}$ curves are measured in both scan directions: (i) reverse scan from 1.2 to $-0.2 \mathrm{~V}$ and (ii) forward scan from -0.2 to $1.2 \mathrm{~V}$, and the scan rate is kept at $200 \mathrm{mV} / \mathrm{s}$. Prior to the J-V scans, the PCE deduced from the maximum power point measurement was tracked for $120 \mathrm{~s}$. All the PV measurements are performed while masking the active area with an aperture of $0.09 \mathrm{~cm}^{2}$ in a metal mask and at room temperature.

\section{RESULTS}

\section{A. Performance of perovskite cells with ETLs}

The $\mathrm{SnO}_{2}$ and $\mathrm{TiO}_{2}$ layers are first tested as ETLs in combination with a PCBM interlayer in a $\mathrm{p}-\mathrm{i}-\mathrm{n}$ cell architecture, in order to compare our results with the relevant literature and with the reference cell without a metal oxide layer. All cell architectures are reported in Fig. S2, Sec. III, in the supplementary material. ${ }^{73}$ $20 \mathrm{~nm}$-thick metal oxide layers in combination with PCBM are incorporated into the perovskite cells. The corresponding $\mathrm{J}-\mathrm{V}$ curves are shown in Fig. 1: only a small hysteresis is observed in all

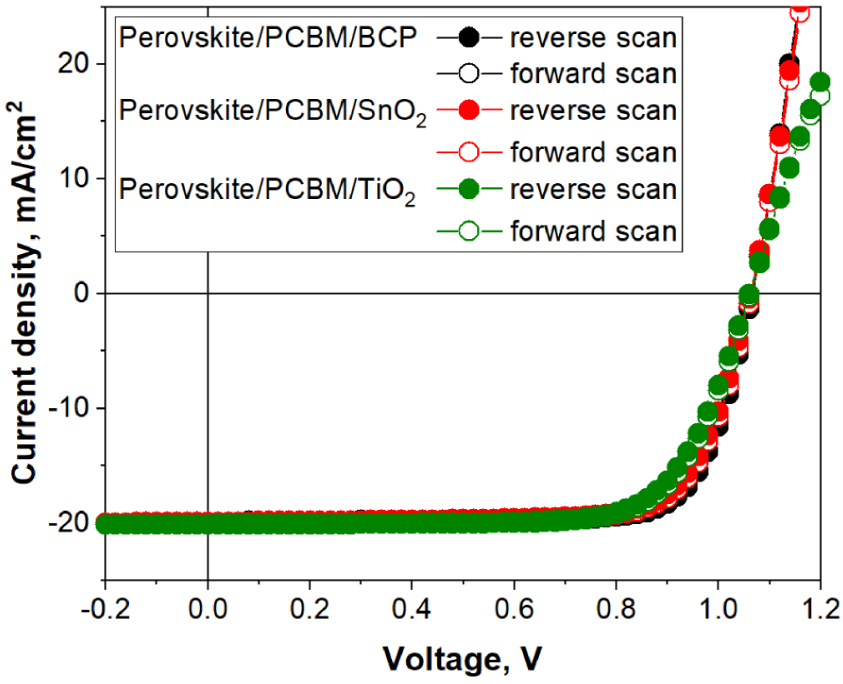

FIG. 1. J-V curves of p-i-n perovskite solar cells with the configurations shown in Figs. S2(a)-S2(b), Sec. III, in the supplementary material (Ref. 73). The metal oxide thickness is $20 \mathrm{~nm}$.

cases. The use of metal oxides results in similar PCEs: $16.1 \%$ (reverse scan) and $16.0 \%$ (deduced from MPPT, note that all MPPT are shown in Fig. S3, Sec. IV, in the supplementary material ${ }^{73}$ ) for $\mathrm{SnO}_{2} ; 15.6 \%$ (reverse scan) and $15.5 \%$ (MPPT) for $\mathrm{TiO}_{2}$ versus $16.5 \%$ (reverse scan) and $16.1 \%$ (MPPT) for the reference cell. The performance of the cells with both metal oxides is consistent with the results in the literature and comparable to the performance of the cell with the organic ETL only. ${ }^{17,19,20}$ All three $\mathrm{J}-\mathrm{V}$ curves exhibit negligible hysteresis. The adoption of $\mathrm{TiO}_{2}$ results in lower fill factor (FF) possibly related to the lower conductivity of amorphous $\mathrm{TiO}_{2}$, when compared to $\mathrm{SnO}_{2}$. Thus, we confirm that the quality of both the perovskite absorber and the metal oxides grown on PCBM are satisfactory to produce working devices.

Next, we discuss the results of ALD processing of both oxides directly on the perovskite absorber. XRD patterns in Fig. S5, Sec. V, in the supplementary material ${ }^{73}$ show no indication of perovskite structure degradation, usually associated with the presence of lead halide crystalline peaks. Based on literature results (see Table I), we process $6 \mathrm{~nm}$-thick metal oxides on top of the perovskite and evaluate the cell performance. Note that the deposition of thicker $\mathrm{SnO}_{2}$ and $\mathrm{TiO}_{2}$ films did not result in improvement in the device performance (Fig. S4, Sec. IV, in the supplementary material ${ }^{73}$ ). The J-V curves for the cell structure reported in Fig. S2(c), Sec. III, in the supplementary material, ${ }^{73}$ are shown in Fig. 2 . Both cells show the presence of a large J-V hysteresis and reduced performance compared to that of the PCBM/metal oxide-based cells. In the case of $\mathrm{SnO}_{2}$, contributing to the poor performance, we also observe a strong s-shaped character in the J-V curves. The efficiency of cells with $\mathrm{SnO}_{2}$ falls within the range of efficiencies reported in the literature. ${ }^{8,10}$ Nonetheless, a more detailed comparison of the obtained 


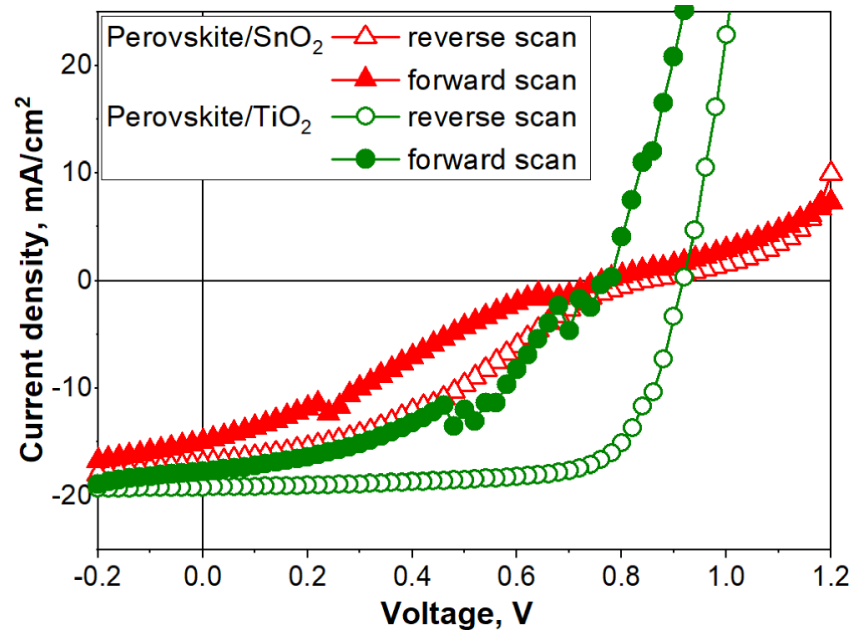

FIG. 2. J-V curves of $p$-i-n perovskite solar cells with the configuration shown in Fig. S2(b), Sec. III, in the supplementary material (Ref. 73). PV parameters are reported in Table I.

results with literature data cannot be carried out due to the different halide ratios, nature of cations, and synthesis of the absorber.

For the case of $6 \mathrm{~nm} \mathrm{TiO}_{2}$ serving as the ETL, despite the large J-V hysteresis, we obtain a promising PCE of 13.6\% (reverse scan) and $11 \%$ (deduced from MPPT) (MPPT in Fig. S3, Sec. IV, in the supplementary material ${ }^{73}$ ). To the best of our knowledge, cells with only $\mathrm{TiO}_{2}$ serving as an ETL have not been previously reported. The poor performance of $\mathrm{SnO}_{2}$, compared to $\mathrm{TiO}_{2}$, as the sole ETL might be caused by chemical changes taking place at the perovskite surface upon ALD processing and/or by the quality of the $\mathrm{SnO}_{2}$ film in its initial growth stage. In addition, an unfavorable band alignment may develop between the perovskite and $\mathrm{SnO}_{2}$. We address these factors in Secs. III B and III C by combining XPS and UPS analyses carried out on the perovskite/metal oxide interface.

\section{B. Chemical changes at the perovskite/metal oxide interface}

In order to analyze the chemical changes occurring at the perovskite surface upon ALD processing of metal oxides, XPS is carried out on the pristine perovskite and on perovskite/metal oxide systems, for a wide range of metal oxide thicknesses (from 0.3 to above $10 \mathrm{~nm}$ ). The thickness of the metal oxide layers is determined according to the procedure outlined in Sec. VI in the supplementary material. ${ }^{73}$ Table II and Table SII, Sec. VII, in the supplementary material ${ }^{73}$ report the $\mathrm{BE}$ values for the features present in the perovskite and perovskite/metal oxide spectra, which are shown next. The left part of Table II reports the BE values for the pristine perovskite spectra, which are in agreement with other works. ${ }^{41,42}$ Next to these spectra, additional features (right part of Table II) appear when metal oxides are grown on perovskites,
TABLE II. Binding energy values of XPS spectral features for the pristine perovskite, perovskite $/ 3 \mathrm{~nm} \mathrm{SnO}_{2}$, and perovskite $/ 3 \mathrm{~nm} \mathrm{TiO}$.

\begin{tabular}{|c|c|c|c|}
\hline \multirow{2}{*}{$\begin{array}{l}\text { XPS } \\
\text { spectral } \\
\text { feature }\end{array}$} & \multirow{2}{*}{$\begin{array}{c}\text { BE values of } \\
\text { pristine perovskite } \\
(\mathrm{eV})\end{array}$} & \multicolumn{2}{|c|}{$\mathrm{BE}$ values of new features for } \\
\hline & & $\begin{array}{c}\text { perovskite } / \mathrm{SnO}_{2} \\
(\mathrm{eV})\end{array}$ & $\begin{array}{c}\text { perovskite/ } / \mathrm{TiO}_{2} \\
(\mathrm{eV})\end{array}$ \\
\hline $\mathrm{Br}-3 \mathrm{~d}_{5 / 2}$ & 68.7 & 69.5 & N/A \\
\hline Br- $3 d_{3 / 2}$ & 69.8 & 70.6 & $\mathrm{~N} / \mathrm{A}$ \\
\hline $\mathrm{I}-3 \mathrm{~d}_{5 / 2}$ & 619.5 & 620.5 & $\mathrm{~N} / \mathrm{A}$ \\
\hline $\mathrm{I}-3 \mathrm{~d}_{3 / 2}$ & 631.0 & 632.0 & N/A \\
\hline $\mathrm{Pb}-4 \mathrm{f}_{7 / 2}$ & 138.7 & 139.3 & \\
\hline $\mathrm{Pb}-4 \mathrm{f}_{5 / 2}$ & 143.6 & 144.2 & \\
\hline $\mathrm{N}-1 \mathrm{~s}$ & 400.8 & \multicolumn{2}{|c|}{ Range of BE: $398.3-399.9$} \\
\hline Cs $-3 d_{5 / 2}$ & 725.1 & \multicolumn{2}{|c|}{ N/A } \\
\hline Cs- $3 d_{3 / 2}$ & 739.0 & \multicolumn{2}{|c|}{ N/A } \\
\hline
\end{tabular}

pointing to the formation of new chemical states found for I, Br, $\mathrm{Pb}$, and $\mathrm{N}$ spectra upon ALD processing.

Figures $3(\mathrm{a})-3(\mathrm{c})$ show the changes that the $\mathrm{I}-3 \mathrm{~d}_{5 / 2}$ spectrum of the pristine perovskite undergoes upon $3 \mathrm{~nm}$ metal oxide deposition. Similarly, Figs. 4(a)-4(c) address the changes for the Br-3d spectrum. In the case of $\mathrm{TiO}_{2}$ growth, no new features are detected [Figs. 3(b) and 4(b)]. Instead, as a result of the growth of $\mathrm{SnO}_{2}$, additional halogen-related contributions are detected at higher $\mathrm{BE}$ values than those associated with pristine perovskites [Figs. 3(a) and 4(a)]. Figures 3(d) and 3(e) and Figs. 4(d) and 4(e) show the trends of the peak area evolution of the halide species in the perovskite and of the newly formed species upon $\mathrm{SnO}_{2}$ and $\mathrm{TiO}_{2}$ growth, respectively.

The trend of the $\mathrm{I}-3 \mathrm{~d}_{5 / 2}$ peak area related to pristine perovskite [Fig. 3(d)] follows the theoretical exponential decay due to the increasing thickness of metal oxide film atop. The exponential decay is described by Eq. S2 in Sec. V in the supplementary material. ${ }^{73}$ This is expected for the iodine contribution in pristine perovskite since $\mathrm{I}-3 \mathrm{~d}_{5 / 2}$ is selected for the determination of the metal oxide thickness, as discussed in Sec. VI in the supplementary material. ${ }^{73}$ The trend of the perovskite-related $\mathrm{Br}-3 \mathrm{~d}_{5 / 2}$ spectral area shows, instead, a deviation with respect to the theoretical exponential decay in Figs. 4(d) and $4(\mathrm{e})$. This suggests that, upon metal oxide deposition, there is an excess of perovskite-related $\mathrm{Br}^{-}$species (with respect to $\mathrm{I}^{-}$), which develops at the perovskite/metal oxide interface.

The newly formed species observed in Figs. 3(d) and 4(d) are found only in the case of $\mathrm{SnO}_{2}$. The observed initial rise suggests their formation, while the decay can be associated with the attenuation of the signal because of the increase in metal oxide thickness. Therefore, we can conclude that the new halogen-related species accumulate at the perovskite $/ \mathrm{SnO}_{2}$ interface and are possibly embedded in the metal oxide film in its early growth stage. This accumulation of molecular halides is expected to lead to a resistive $\mathrm{SnO}_{2}$, therefore contributing to the observed s-shaped J-V curve in Fig. 2 for the PSC structure implementing $\mathrm{SnO}_{2}$ as the ETL.

Halogen accumulation near the interface has been reported earlier in the literature, in the case of (FA,MA) $\mathrm{Pb}(\mathrm{I}, \mathrm{Br})_{3} / \mathrm{SnO}_{2}$ using XPS depth profiling. However, no identification of new chemical states has been discussed so far. ${ }^{8}$ The BE values observed 

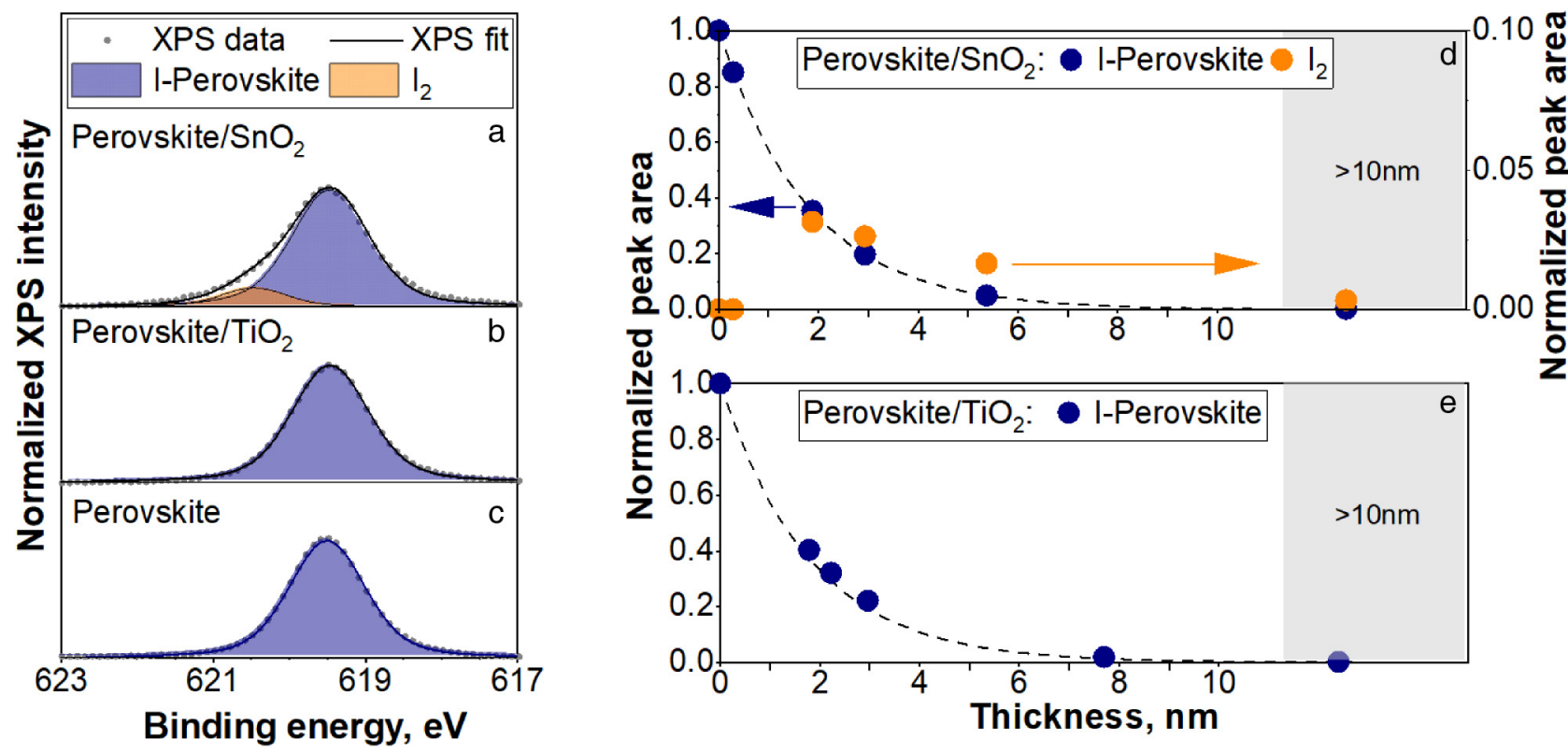

FIG. 3. $1-3 \mathrm{~d}_{5 / 2}$ spectra for (a) perovskite/3 $\mathrm{nm} \mathrm{SnO}{ }_{2}$, (b) perovskite/ $3 \mathrm{~nm} \mathrm{TiO}{ }_{2}$, and (c) pristine perovskite. Each spectrum is normalized to the peak intensity of the pristine perovskite. Intensity evolution of the $\mathrm{I}-3 \mathrm{~d}_{5 / 2}$ peak for (d) perovskite/ $\mathrm{SnO}_{2}$ and (e) perovskite/TiO ${ }_{2}$. In (d) and (e), dashed lines show the attenuation of the $\mathrm{I}-3 \mathrm{~d}_{5 / 2}$ signal upon metal oxide deposition on the perovskite.
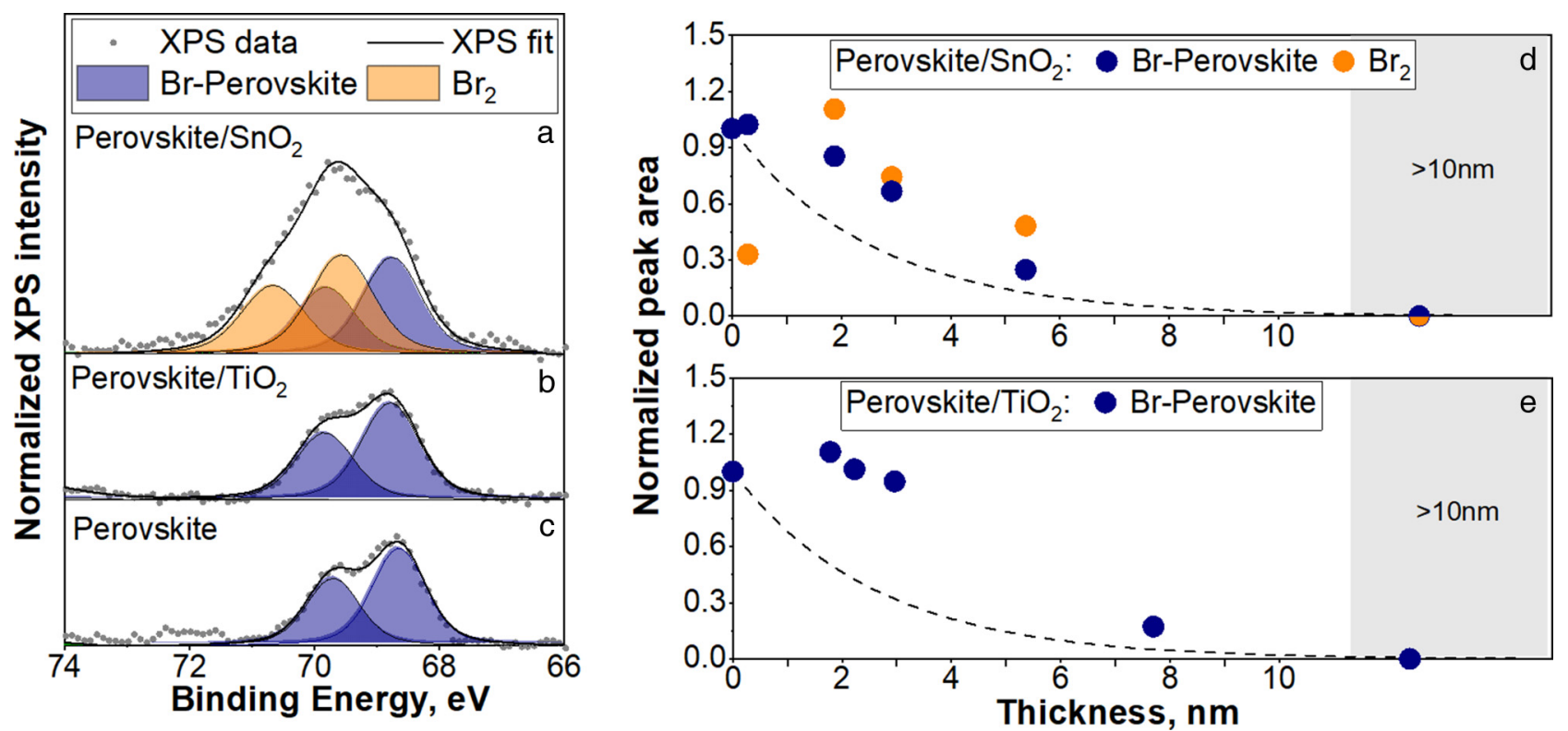

FIG. 4. Br-3d spectrum for (a) perovskite/3 $\mathrm{nm} \mathrm{SnO}{ }_{2}$, (b) perovskite/3 $\mathrm{nm} \mathrm{TiO}_{2}$, (c) and pristine perovskite. Each spectrum is normalized to the peak intensity of the pristine perovskite. Intensity evolution of $\mathrm{Br}_{-} 3 \mathrm{~d}_{5 / 2}$ for (d) perovskite/ $/ \mathrm{SnO}_{2}$ and (e) perovskite/TiO $\mathrm{O}_{2}$. In (d) and (e), dashed lines show the theoretical attenuation of the $\mathrm{Br}_{-} 3 \mathrm{~d}_{5 / 2}$ signal upon metal oxide deposition on the perovskite. 
in our studies strongly suggest the formation of $\mathrm{X}_{2}$ (where $\mathrm{X}=\mathrm{I}$ or $\mathrm{Br}),{ }^{43-46}$ although $\mathrm{X}_{3}^{-}$species and oxyhalides cannot be totally excluded. ${ }^{44,47,48}$ Instead, upon ALD of $\mathrm{TiO}_{2}$ [Figs. 3(e) and 4(e)] as well as of $\mathrm{Al}_{2} \mathrm{O}_{3}$ (Fig. S11, Sec. VI, in the supplementary material $^{73}$ ), halogen species formation is not observed. It is also worth noting that the formation of $\mathrm{I}_{2}$ and $\mathrm{Br}_{2}$ at the interface occurs also for shorter exposure times of the perovskite to the TDMA-Sn precursor, as concluded from experiments on spatial-ALD (S-ALD) processing of $\mathrm{SnO}_{2}$, carried out under atmospheric pressure conditions (Fig. S12, Sec. VII, in the supplementary material $^{73}$ ).

When comparing the trends of $\mathrm{I}_{2}$ and $\mathrm{Br}_{2}$ as a function of the $\mathrm{SnO}_{2}$ thickness [Figs. 3(d) and 4(d)], it can be observed that the $\mathrm{Br}_{2}$ contribution is larger than the one associated with $\mathrm{I}_{2}$. The pristine perovskite is iodine-rich (i.e., the XPS I:Br ratio is 17:1) at the surface, whereas we detect an $\mathrm{I}_{2}: \mathrm{Br}_{2}$ ratio of $0.5: 1$ after $\mathrm{SnO}_{2}$ processing (for all film thicknesses used). This observation indicates that a larger amount of bromine species is present at the perovskite/ $\mathrm{SnO}_{2}$ interface.

Next, we discuss the changes occurring in the $\mathrm{Pb}-4 \mathrm{f}$ spectral feature upon metal oxide deposition, as shown in Figs. 5(a) and 5(b). We observe the development of a lead-containing species with a doublet at larger $\mathrm{BE}$ values than that of the $\mathrm{Pb}^{2+}$ doublet in pristine perovskite. The corresponding evolution of the peak area as a function of the metal oxide thickness related to $\mathrm{Pb}^{2+}$ perovskite species follows the theoretical trend, similar to the $\mathrm{I}^{-}$perovskite species, suggesting that the $\mathrm{Pb} / \mathrm{I}$ ratio at the perovskite interface does not change during the growth of the metal oxide films. The trend of the peak area evolution of the newly formed $\mathrm{Pb}$ species [Figs. 5(d) and 5(e)] points out to its accumulation at the perovskite/metal oxide interface.

The $\mathrm{BE}$ values of the new $\mathrm{Pb}$ species do not correspond to $\mathrm{PbO}$ (Ref. 41) or metallic $\mathrm{Pb} .{ }^{49,50}$ Instead, they point to the formation of $\mathrm{PbX}_{2}$ species, which are decomposition products of the perovskite where $\mathrm{Pb}^{2+}$ holds the same oxidation state. ${ }^{51,52}$ The earlier addressed accumulation of $\mathrm{Br}^{-}$species at the interface confirms the formation of lead halide, specifically $\mathrm{PbBr}_{2}$, upon the deposition of $\mathrm{SnO}_{2}$ and $\mathrm{TiO}_{2}$, whereas no evidence of $\mathrm{PbI}_{2}$ formation can be found from XPS. Since no trace of $\mathrm{PbBr}_{2}$ (as well as $\mathrm{PbI}_{2}$ ) is found in the XRD patterns (Fig. S5, Sec. V, in the supplementary material ${ }^{73}$ ), we can indeed conclude that $\mathrm{PbBr}_{2}$ formation is limited and confined to the perovskite surface and likely has an amorphous structure, making it undetectable by XRD. $\mathrm{PbBr}_{2}$ formation is also observed for the perovskite/ $\mathrm{Al}_{2} \mathrm{O}_{3}$ system (Fig. S11, Sec. VI, in the supplementary material ${ }^{73}$ ) and in the case of S-ALD processing (Fig. S12, Sec. VII, in the supplementary material ${ }^{73}$ ). The observation of ultrathin $\mathrm{PbBr}_{2}$ at the interface for iodine-rich perovskite has not been reported before, to the best of our knowledge. Its presence at the interface between the perovskite and the metal oxides can cause the accumulation of charge carriers, due to its resistive character. Charge accumulation is then held responsible for the hysteresis behavior observed in the J-V curves (Fig. 2).

The N-1s spectra and their evolution are presented in Figs. S10(a)-S10(c), Sec. VI, in the supplementary material. ${ }^{73}$ The $\mathrm{BE}$ of the feature related to the FA cation of perovskite $(400.8 \mathrm{eV})$
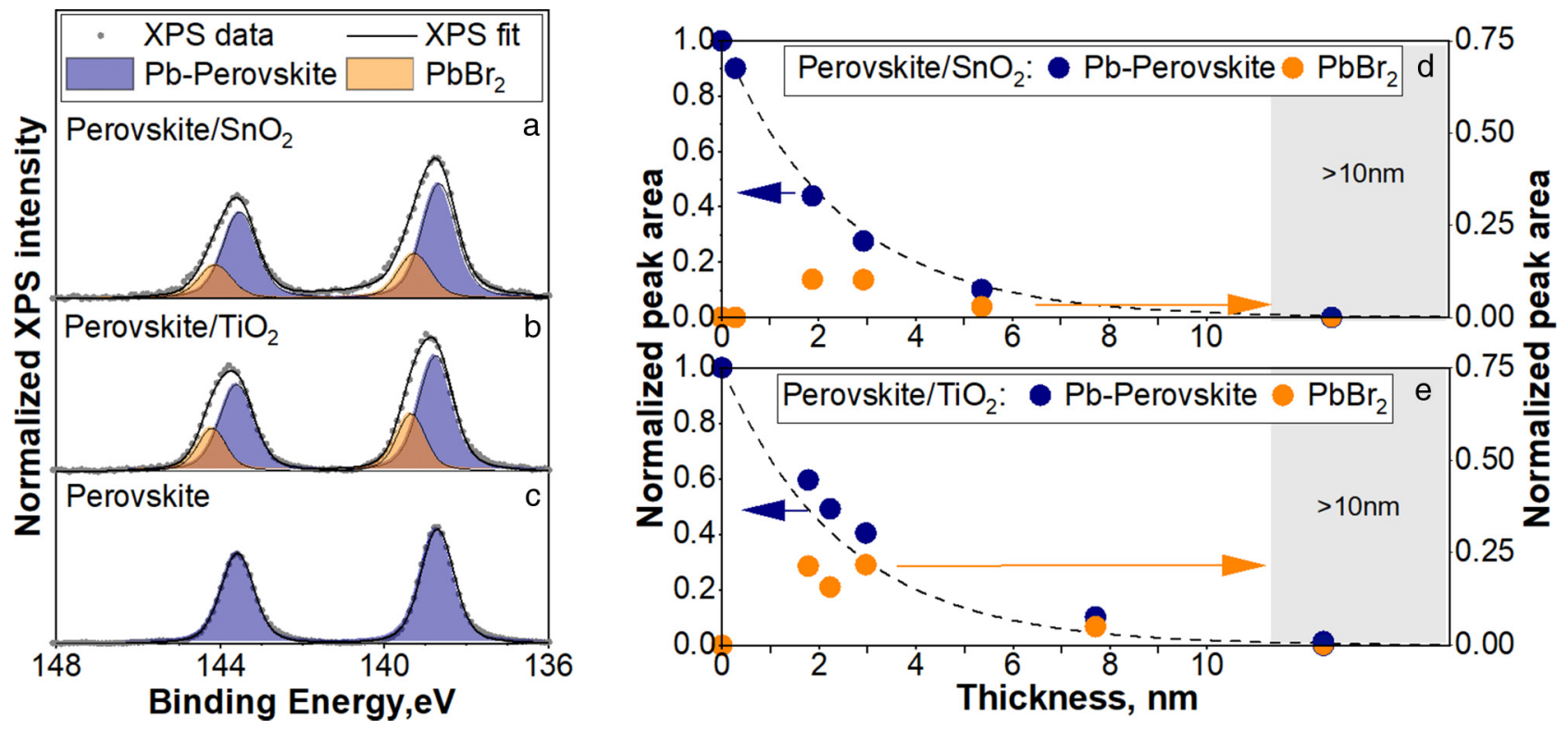

FIG. 5. Pb-4f spectrum for (a) perovskite/3 $\mathrm{nm} \mathrm{SnO}$, (b) perovskite/3 $\mathrm{nm} \mathrm{TiO}$, and (c) pristine perovskite. Each spectrum is normalized to the peak intensity of the pristine perovskite. Note that the $\mathrm{Sn}-4 \mathrm{~s}$ peak, not shown in Fig. $5(\mathrm{a})$, overlaps with the $\mathrm{Pb}-4 \mathrm{f}_{7 / 2}$ peaks (it is broad and centered at $139.0 \mathrm{eV}$ ); it is however considered during the deconvolution of the $\mathrm{Pb}-4 \mathrm{f}$ spectrum. Peak intensity evolution of the two $\mathrm{Pb}-4 \mathrm{f}$ contributions for (d) perovskite/ $/ \mathrm{SnO}_{2}$ and (e) perovskite/TiO $\mathrm{O}_{2}$. In (d) and (e), dashed lines show the theoretical attenuation of the $\mathrm{Pb}-4 \mathrm{f}_{7 / 2}$ signal upon metal oxide deposition on the perovskite. 
is present in both pristine perovskite and perovskite/metal oxide samples. The peak area attenuation follows the expected trend [Figs. S10(f)-S10(g), Sec.VI, in the supplementary material ${ }^{73}$ ], just like the $\mathrm{Pb}^{2+}$ and $\mathrm{I}^{-}$species of the pristine perovskite, suggesting that FA is not depleted from the interface under the processing conditions used in this work. In addition, both perovskite/metal oxide systems show new nitrogen peaks in the $\mathrm{BE}$ range of $398.3-399.9 \mathrm{eV}$. A contribution to these peaks derives from nitrogen species incorporated in the metal oxides due to the residual ligands of the metal precursor molecules TDMA-Sn and TDMA-Ti. ${ }^{53,54}$ This is observed also in the case of growth on c-Si substrates [Figs. S10(d)-S10(e), Sec. VI, in the supplementary material ${ }^{73}$ ]. Another contribution in terms of new nitrogen species can arise from the chemical modification of the FA cation, as observed in the perovskite $/ \mathrm{Al}_{2} \mathrm{O}_{3}$ case, where a nitrogen-free ALD precursor is used [Fig. S11(b), Sec. VI, in the supplementary material ${ }^{73}$ ]. Given the overlap between the two contributions in terms of $\mathrm{BE}$ values, we cannot exclude that the chemical modification of FA occurs upon deposition of $\mathrm{TiO}_{2}$ and $\mathrm{SnO}_{2}$.

\section{Chemical composition of metal oxide films and energetics of the perovskite/metal oxide interface}

The oxygen-to-metal ratio (O:M) for both metal oxide films grown on perovskites is evaluated and reported in Fig. 6(a). As a reference, we observe that, when $\mathrm{SnO}_{2}$ film is grown on PCBM, the O:M ratio is $\sim 2$, regardless of the film thickness. Note that for the calculation of the stoichiometry of the metal oxides, only the chemical state belonging to the oxygen bonded to the metal is considered. Other chemical states detected in the O-1s spectra and belonging to carbonaceous states like the $\mathrm{C}=\mathrm{O}$ bond or the $\mathrm{C}-\mathrm{O}$ bonds found in PCBM or to the $-\mathrm{OH}$ groups present on the surface of the perovskite and on the metal oxides are excluded from the estimation of the O:M ratio. For the perovskite/ $\mathrm{SnO}_{2}$ case, thin films are found to be significantly oxygen-deficient, while for $\mathrm{SnO}_{2}$ thicknesses above $10 \mathrm{~nm}$, the ratio increases toward 2. The substoichiometry in the initial stage of $\mathrm{SnO}_{2}$ growth suggests the presence of both $\mathrm{Sn}^{4+}$ and $\mathrm{Sn}^{2+}$ states. Unfortunately, the BE values of these states cannot be resolved in the Sn-3d XPS spectrum. ${ }^{55}$

Therefore, to determine the presence of defects in the metal oxide films, UPS measurements are carried out on films of different thicknesses deposited on top of the perovskite. For $\mathrm{SnO}_{2}$, we observe a contribution to the density of states (DOS), assigned to $\mathrm{Sn}^{2+}$ with the edge located $1.8 \mathrm{eV}$ above the valence band maximum (VBM) shown in Fig. 6(b). Oxygen deficiency in $\mathrm{SnO}_{2}$ is expected to give rise to localized occupied electronic states within the bandgap of $\mathrm{SnO}_{2}$ located above the valence band maximum. ${ }^{56-59}$ They appear as a result of hybridization between $\mathrm{Sn}-4 \mathrm{~d}, \mathrm{Sn}-5 \mathrm{~s}$, and $\mathrm{O}-2 \mathrm{p}$ states, bear excitonic character, and are more pronounced in the case of amorphous $\mathrm{SnO}_{2}$ films. ${ }^{60-62}$ In theoretical works, ${ }^{63,64}$ it was suggested that these $\mathrm{Sn}^{2+}$ states develop upon removal of oxygen from bridging positions. So far, they have been experimentally observed $^{61,62}$ only upon ion bombardment or heating in ultrahigh vacuum conditions.

Furthermore, this subgap defect contribution is found to decrease with increasing $\mathrm{SnO}_{2}$ thickness as reported in Fig. S13(a) A, Sec. VIII (please refer to the discussion on the deconvolution of defect DOS in Sec. VIII in the supplementary material). ${ }^{73}$ Since
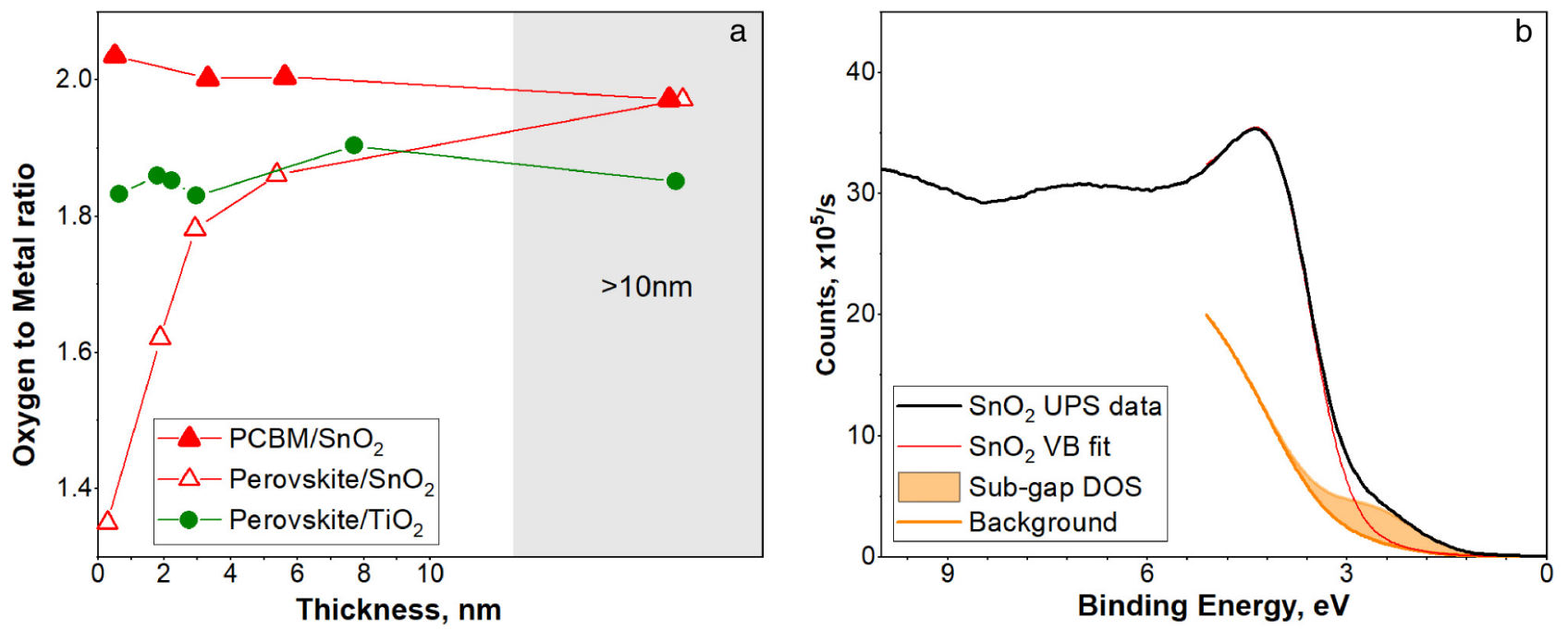

FIG. 6. (a) Oxygen-to-metal ratio, derived from XPS spectra, as a function of the metal oxide thickness for $\mathrm{SnO}_{2}$ ( $\mathrm{grown}$ on perovskite and PCBM) and $\mathrm{TiO}_{2}$. Only the contributions of oxygen peaks originating from $\mathrm{O}-\mathrm{Sn}$ and $\mathrm{O}-\mathrm{Ti}$ bonds are considered in these calculations; extra contributions from surface $\mathrm{O}-\mathrm{H}$ or $\mathrm{O}-\mathrm{C}$ species are excluded. (b) UPS valence band spectra of the $6 \mathrm{~nm} \mathrm{SnO}_{2}$ layer grown on the perovskite with fitted subgap density of states, as discussed in Sec. VIII in the supplementary material (Ref. 73). 
UPS probes up to a depth of $\sim 1 \mathrm{~nm}$, this analysis reveals that the defects are located at the perovskite $/ \mathrm{SnO}_{2}$ interface rather than on the surface of $\mathrm{SnO}_{2}$ film in contrast to the literature observations mentioned above.

In the $\mathrm{TiO}_{2}$ case [Fig. 6(a)], the O:M ratio is constant as a function of the film thickness and in the range of 1.8-1.9. Moreover, we do not observe $\mathrm{Ti}^{3+}$ states in the $\mathrm{Ti}-2 \mathrm{p}$ spectra [Fig. S8(h), Sec. VII, in the supplementary material ${ }^{73}$ ]. Such states are reported to give rise to a subgap peak located below the $\mathrm{E}_{\mathrm{f}}$ and $1 \mathrm{eV}$ above the VBM of $\mathrm{TiO}_{2}{ }^{65-68}$ In parallel, the UPS spectra of $\mathrm{TiO}_{2}$ grown on perovskite [Fig. S13(b), Sec. VIII, in the supplementary material ${ }^{73}$ ] do not show any evidence for $\mathrm{Ti}^{3+}$ states in the valence spectrum.

\section{DISCUSSION}

The evidence of $\mathrm{SnO}_{2}$ substoichiometry and the presence of subgap defect states located at the interface with the perovskite suggest that a redox reaction occurs at the early phase of $\mathrm{SnO}_{2}$ growth due to the interaction of the metal precursor with the perovskite substrate. Specifically, we speculate that the $\mathrm{Sn}$ (IV) metal center is reduced to $\mathrm{Sn}(\mathrm{II})$, whereas halide $\left(\mathrm{X}^{-}\right)$species, originating either from the perovskite itself or from its decomposition products (e.g., $\mathrm{PbX}_{2}, \mathrm{HX}$, or $\mathrm{FAX}$ ), are oxidized to $\mathrm{X}_{2}\left(\mathrm{Br}_{2}\right.$ and $\mathrm{I}_{2}$ ). We exclude that a redox reaction involving the participation of halides and the Sn(IV) atoms in the metal oxide is taking place, since high temperatures would be required. ${ }^{61}$ Instead, we suggest that it is the metal center in the metalorganic precursor that interacts with the perovskite. As a result, an oxygen defective $\mathrm{SnO}_{2}$ film containing $\mathrm{Sn}$ (II) states and embedded halogen molecules develops. Both chemical changes contribute to the resistive character of $\mathrm{SnO}_{2}$, which results in the s-shaped $\mathrm{J}-\mathrm{V}$ curves for cells implementing $\mathrm{SnO}_{2}$ ETL. Earlier [Figs. 3(a) and 4(a)], we referred to diatomic halogen formation at the perovskite/ $\mathrm{SnO}_{2}$ interface, opposite to the case of the perovskite/ $\mathrm{TiO}_{2}$ interface, where also substoichiometry is not observed. This difference strongly suggests that TDMA-Ti and TDMA-Sn precursors behave differently when chemisorbing on the perovskite. Most certainly, the difference in electronegativity between the two metal atoms plays a role.

Next, we evaluate the valence band alignment of the perovskite/metal oxide systems, using UPS. Specifically, we assess the charge selectivity of $\mathrm{SnO}_{2}$ and $\mathrm{TiO}_{2}$ by considering the presence of DOS related to defects in the case of $\mathrm{SnO}_{2}$. UPS is a widely adopted technique that provides information about energetics and band alignment in perovskite cells. ${ }^{69}$ Using the values of $\mathrm{E}_{\mathrm{f}}$ and VBM extracted from UPS measurements ${ }^{70}$ (Fig. S14, Sec. VIII, in the supplementary material ${ }^{73}$ ), we present the energy band diagram in Fig. 7 (under dark conditions) for the pristine perovskite and perovskite $/ 6 \mathrm{~nm}$-thick metal oxides. The energy levels are aligned to the $\mathrm{E}_{\mathrm{f}}$ position, in order to unravel other potential interfacial effects, such as dipole formation. As a matter of fact, the formation of a dipole is observed for both systems, characterized by the shift of the vacuum level of $0.2 \mathrm{eV}$ (for the $\mathrm{SnO}_{2}$ case) and $0.4 \mathrm{eV}$ (for the $\mathrm{TiO}_{2}$ case). The presence of the dipole is supported by the observation of shifts in the $\mathrm{BE}$ values of the perovskite (Sec. II in the supplementary material ${ }^{73}$ ) upon deposition of metal oxides and could contribute to the presence of hysteresis in the current-voltage characteristics of the cells (Fig. 2).

The subgap DOS related to the defect states, present at the perovskite/ $\mathrm{SnO}_{2}$ interface, is schematically depicted in Fig. 7 as a probability density function in the region above the $\mathrm{VBM}$ of $\mathrm{SnO}_{2}$ for the $6 \mathrm{~nm}$ film. The presence of the subgap defect states in thin $\mathrm{SnO}_{2}$ films, which effectively broaden the VB, decreases the $\mathrm{SnO}_{2}$ selectivity as an electron transport layer. The energetic alignment of the defect edge with the VBM of the perovskite will favor hole injection into the defect states of $\mathrm{SnO}_{2}$. Such defect states act as

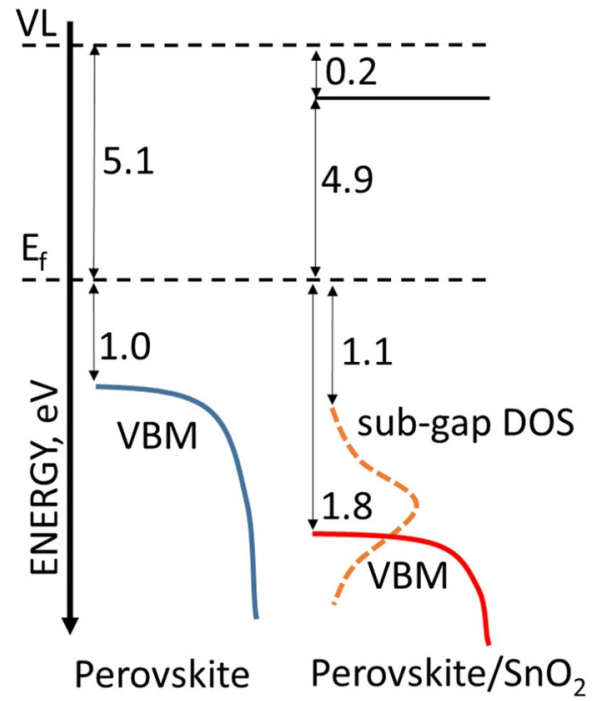

$b$

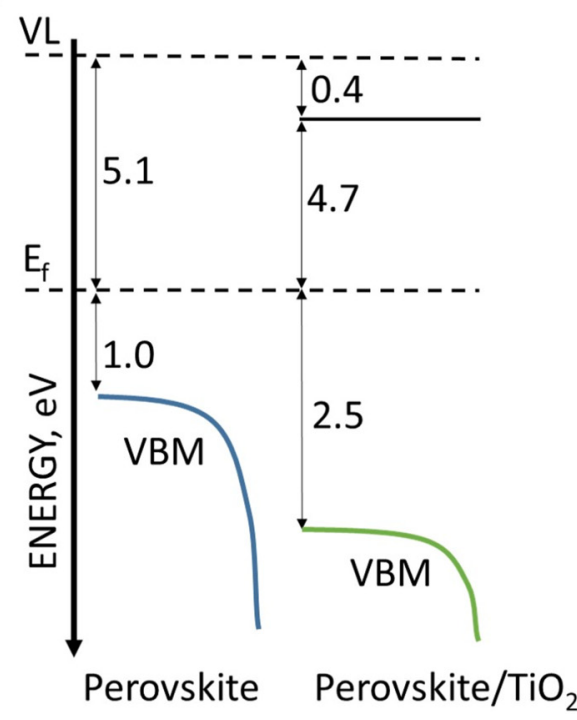

FIG. 7. Energy level diagrams for the pristine perovskite (grown on ITO/ PTAA) and upon deposition of $6 \mathrm{~nm}$ of (a) $\mathrm{SnO}_{2}$ or (b) $\mathrm{TiO}_{2}$. The energy levels are aligned to $\mathrm{E}_{\mathrm{f}}$. The positions of the valence band maxima (VBM), vacuum levels, and the edge of subgap DOS for perovskite/ $\mathrm{SnO}_{2}$ case are shown in the figure, whereas the conduction band minima are not reported. 
hole traps ${ }^{59}$ and contribute to increase hole-electron recombination processes at the perovskite/ $\mathrm{SnO}_{2}$ interface. Figure 7 does not include the conduction band minimum for $\mathrm{SnO}_{2}$ : it is experimentally complex to determine it for very thin metal oxides grown on perovskite. However, theoretical calculations ${ }^{56}$ predict that the presence of oxygen vacancies within the $\mathrm{SnO}_{2}$ give rise to unoccupied tail states below the CBM effectively reducing the bandgap of the material. ${ }^{56}$ Such an observation would enhance the hole-electron recombination processes mentioned above. In conclusion, the poor cell performance reported in Fig. 2 is attributed to the loss of $\mathrm{SnO}_{2}$ electron selectivity and recombination processes.

Instead, for the perovskite/ $\mathrm{TiO}_{2}$ interface, which lacks subgap states, the hole injection is impeded due to the favorable VBM offset between the perovskite and $\mathrm{TiO}_{2}(2.5 \mathrm{eV})$. This observation aligns with the promising p-i-n cell efficiency when $\mathrm{TiO}_{2}$ is adopted as the ETL.

\section{SUMMARY AND CONCLUSIONS}

This manuscript focuses on the factors limiting the perovskite solar cell efficiency when metal oxides processed by ALD are adopted as ETLs and grown directly on the perovskite absorber. To this purpose, we carry out a systematic and in-depth investigation of the chemical changes occurring at the interface between the perovskite and $\mathrm{SnO}_{2}$ and $\mathrm{TiO}_{2}$ and correlate them to the p-i-n cell performance.

The dual cation (Cs,FA)-based perovskite withstands ALD processing, since the bulk of the material remains unaltered upon the growth of the investigated metal oxides. For both metal oxides, we report the common interfacial changes related to the formation of a thin $\mathrm{PbBr}_{2}$ layer and the formation of a dipole, based on XPS and UPS analyses. These changes may contribute to the observed large J-V hysteresis in both cases.

In the case of $\mathrm{SnO}_{2}$ as the ETL, we observe a poor cell performance and strongly s-shaped J-V curves. We relate this result to the chemical changes directly affecting the electronic properties of $\mathrm{SnO}_{2}$ metal oxide at the interface. These chemical changes are the formation of halogen molecules $\left(\mathrm{Br}_{2}\right.$ and $\left.\mathrm{I}_{2}\right)$ and the presence of an oxygen deficiency of $\mathrm{SnO}_{2}$ in the early phase of its growth. This substoichiometry is accompanied by the development of subgap states related to $\mathrm{Sn}^{2+}$ above the valence band maximum, which act as hole traps at the perovskite/ $\mathrm{SnO}_{2}$ interface, subsequently promoting charge recombination and negatively affecting the performance of the cell. The observed changes at the perovskite $/ \mathrm{SnO}_{2}$ interface have been attributed to a redox reaction between halide species $\left(\mathrm{I}^{-}\right.$and $\mathrm{Br}^{-}$) of the perovskite or its decomposition products and the $\mathrm{Sn}(\mathrm{IV})$ metal center of the TDMA-Sn precursor.

Instead, when adopting $\mathrm{TiO}_{2}$ as the ETL, we report a promising device performance of $13.6 \%$ (MPPT 11\%). In the case of $\mathrm{TiO}_{2}$ processing, there is no evidence of redox processes between the halides and the $\mathrm{Ti}(\mathrm{IV})$ metal center during film growth. Consequently, the perovskite/ $\mathrm{TiO}_{2}$ interface exhibits no signature of subgap states and has a favorably large VBM offset. We also conclude that $\mathrm{TiO}_{2}$ is a potentially more suitable ETL for $\mathrm{p}-\mathrm{i}-\mathrm{n}$ perovskite cells directly applied on top of the perovskite absorber without the need of an organic interlayer. However, in order to reduce the hysteresis in cells employing $\mathrm{TiO}_{2}$ ETLs, the formation of $\mathrm{PbBr}_{2}$ should be avoided or at least minimized and further investigation on other perovskite compositions is required in order to tackle this problem. Concurrently, investigating the application of an ultrathin passivation layer, carrying a fixed positive charge, like the $\mathrm{PO}_{\mathrm{x}} / \mathrm{Al}_{2} \mathrm{O}_{3}$ bilayer, ${ }^{71,72}$ could be attempted to improve the charge selectivity of the interface between $\mathrm{TiO}_{2}$ and the perovskite to reduce the hysteresis. The use of a $\mathrm{TiO}_{2}$ ETL may then not only be more cost-effective but also more suitable for process upscaling.

Finally, the predominant formation of $\mathrm{Br}_{2}$ at the perovskite/ metal oxide interface suggests investigating a perovskite surface less prone to redox reactions with specific ALD precursors by tuning the halide composition. Moreover, further understanding of the interaction of ALD precursors with the metal halide perovskite, supported by density functional theory (DFT) calculations, is required in order to shed light on the preferential participation to the redox process of $\mathrm{Br}^{-}$species and TDMA-Sn precursor, instead of TDMA-Ti.

As a concluding remark, we consider highly intriguing the fact that nowadays ALD research in perovskite PVs draws the attention of the PV perovskite community in ALD (and spatial-ALD). Therefore, next to control on parameters such as substrate temperature and processing time, we believe that this research field requires major efforts to generate insights into the surface reactions between the specific ALD chemistry and the chemically challenging nature of hybrid metal halide perovskite absorbers.

\section{AUTHORS' CONTRIBUTIONS}

A.E.A.B., C.H.B., and A.T. contributed equally to the work.

\section{ACKNOWLEDGMENTS}

The authors thank Barathi Krishnamoorthy (TU/e) and Cristian A. A. van Helvoirt (TU/e) for the technical support. A.E.A.B. acknowledges financial support from the NWO Joint Solar Programme III (JSP3). C.H.B., A.T., and D.K. acknowledge funding from the Dutch Ministry of Economic Affairs, via the Top-consortia Knowledge and Innovation (TKI) Program "ALD for perovskites" (ALD4PSC, No. TKITOE1409105), "Photovoltaic modules based on a p-i-n stack, manufactured on a roll-to-roll line featuring high efficiency, stability and strong market perspective" (PVPRESS, No. TEUE118010), and "Bridging the voltage gap" (BRIGHT, No. 1721101). M.C. acknowledges the NWO Aspasia Program.

\section{REFERENCES}

${ }^{1}$ See www.nrel.gov/pv/assets/pdfs/best-research-cell-efficiencies.20200406.pdf (accessed 28 May 2020).

${ }^{2}$ A. K. Jena, A. Kulkarni, and T. Miyasaka, Chem. Rev. 119, 3036 (2019).

${ }^{3}$ C. C. Boyd, R. Cheacharoen, T. Leijtens, and M. D. McGehee, Chem. Rev. 119, 3418 (2019).

${ }^{4}$ P. Schulz, D. Cahen, and A. Kahn, Chem. Rev. 119, 3349 (2019).

${ }^{5} \mathrm{~V}$. Zardetto, B. L. Williams, A. Perrotta, F. Di Giacomo, M. A. Verheijen, R. Andriessen, W. M. M. Kessels, and M. Creatore, Sustainable Energy Fuels 1, 30 (2017).

${ }^{6}$ S. Seo, S. Jeong, H. Park, H. Shin, and N. G. Park, Chem. Commun. 55, 2403 (2019).

${ }^{7}$ K. O. Brinkmann, T. Gahlmann, and T. Riedl, Sol. RRL 4, 190033 (2020).

${ }^{8}$ A. Hultqvist, K. Aitola, K. Sveinbjörnsson, Z. Saki, F. Larsson, T. Törndahl, E. Johansson, G. Boschloo, and M. Edoff, ACS Appl. Mater. Interfaces 9, 29707 (2017). 
9. P. Correa Baena et al., Energy Environ. Sci. 8, 2928 (2015).

${ }^{10}$ A. F. Palmstrom et al., Adv. Energy Mater. 8, 1800591 (2018).

${ }^{11}$ Y. Kuang et al., ACS Appl. Mater. Interfaces 10, 30367 (2018).

${ }^{12}$ D. Koushik, W. J. H. Verhees, Y. Kuang, S. Veenstra, D. Zhang, M. A. Verheijen, M. Creatore, and R. E. I. Schropp, Energy Environ. Sci. 10, 91 (2017).

${ }^{13}$ M. Jošt et al., ACS Energy Lett. 4, 583 (2019).

${ }^{14}$ J. A. Raiford, S. T. Oyakhire, and S. F. Bent, Energy Environ. Sci. 13, 1997 (2020).

${ }^{15}$ A. K. Chandiran, A. Yella, M. T. Mayer, P. Gao, M. K. Nazeeruddin, and M. Grätzel, Adv. Mater. 26, 4309 (2014).

${ }^{16}$ K. A. Bush et al., Nat. Energy 2, 17009 (2017).

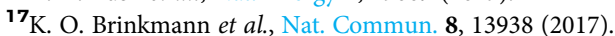

${ }^{18}$ S. Albrecht et al., Energy Environ. Sci. 9, 81 (2016).

${ }^{19}$ S. Seo, S. Jeong, C. Bae, N. G. Park, and H. Shin, Adv. Mater. 30, 1801010 (2018).

${ }^{20}$ R. D. Raninga et al., Nano Energy 75, 104946 (2020).

${ }^{21}$ F. Sahli et al., Nat. Mater. 17, 820 (2018).

${ }^{22}$ N. Rolston et al., Adv. Energy Mater. 8, 1702116 (2018).

${ }^{23}$ M. Kot, K. Henkel, K. Müller, L. Kegelmann, S. Albrecht, N. Tsud, P. Kús, I. Matolinová, and D. Schmeißer, Energy Technol. 7, 1900975 (2019).

${ }^{24}$ C. Das, M. Kot, T. Hellmann, C. Wittich, E. Mankel, I. Zimmermann, D. Schmeisser, M. K. Nazeeruddin, and W. Jaegermann, Cell Rep. Phys. Sci. 1, 100122 (2020).

${ }^{25}$ D. Koushik, W. J. H. Verhees, D. Zhang, Y. Kuang, S. Veenstra, M. Creatore, and R. E. I. Schropp, Adv. Mater. Interfaces 18, 1700043 (2017).

${ }^{\mathbf{2 6}}$ D. Koushik, L. Hazendonk, V. Zardetto, V. Vandalon, M. A. Verheijen, W. M. M. Kessels, and M. Creatore, ACS Appl. Mater. Interfaces 11, 5526 (2019).

${ }^{27}$ D. Choudhury, G. Rajaraman, and S. K. Sarkar, Nanoscale 8, 7459 (2016).

${ }^{28}$ D. Koushik, F. Naziris, J. Melskens, A. Nusteling, V. Zardetto, H. Schut, W. M. M. Kessels, S. W. H. Eijt, and M. Creatore, J. Mater. Chem. C 7, 5275 (2019).

${ }^{29}$ X. Yu, H. Yan, and Q. Peng, Langmuir 35, 6522 (2019).

${ }^{30}$ M. Kot, C. Das, K. Henkel, K. Wojciechowski, H. J. Snaith, and D. Schmeisser, Nucl. Instrum. Methods Phys. Res. Sect. B 411, 49 (2017).

${ }^{31} \mathrm{X}$. Yu, H. Yan, and Q. Peng, ACS Appl. Mater. Interfaces 10, 28948 (2018).

${ }^{32}$ I. S. Kim, D. H. Cao, D. B. Buchholz, J. D. Emery, O. K. Farha, J. T. Hupp, M. G. Kanatzidis, and A. B. F. Martinson, Nano Lett. 16, 7786 (2016).

${ }^{33}$ M. Lv, X. Dong, X. Fang, B. Lin, S. Zhang, X. Xu, J. Ding, and N. Yuan, RSC Adv. 5, 93957 (2015).

${ }^{34}$ P. P. Rajbhandari and T. P. Dhakal, J. Vac. Sci. Technol. A 38, 032406 (2020).

${ }^{35}$ W. Tan, A. B. Bowring, A. S. Babadi, A. C. Meng, R. Tang-Kong, M. D. McGehee, and P. C. McLntyre, Adv. Mater. Interfaces 7, 1902054 (2020).

${ }^{36}$ I. S. Kim and A. B. F. F. Martinson, J. Mater. Chem. A 3, 20092 (2015).

${ }^{37}$ M. Kot, M. Vorokhta, Z. Wang, H. J. Snaith, D. Schmeisser, and J. I. Fledge, Appl. Surf. Sci. 513, 145596 (2020).

${ }^{38} \mathrm{M}$. Stolterfoht et al., Energy Environ. Sci. 12, 2778 (2019).

${ }^{39}$ J. Wang, K. Datta, C. H. L. Weijtens, M. M. Wienk, and R. A. J. Janssen, Adv. Funct. Mater. 29, 1905883 (2019).

${ }^{40}$ M. Jaysankar et al., ACS Energy Lett. 4, 259 (2019).

${ }^{41}$ S. Olthof and K. Meerholz, Sci. Rep. 7, 40267 (2017).

${ }^{42}$ S. Tao, I. Schmidt, G. Brocks, J. Jiang, I. Tranca, K. Meerholz, and S. Olthof, Nat. Commun. 10, 2560 (2019).

${ }^{43}$ J. Zheng, H. T. Liu, B. Wu, C. A. Di, Y. L. Guo, T. Wu, G. Yu, Y. Q. Liu, and D. Ben Zhu, Sci. Rep. 2, 662 (2012).

${ }^{44}$ R. A. Kerner, P. Schulz, J. A. Christians, S. P. Dunfield, B. Dou, L. Zhao, G. Teeter, J. J. Berry, and B. P. Rand, APL Mater. 7, 041103 (2019).

${ }^{45}$ T. Mayer, J. Lehmann, C. Pettenkofer, and W. Jaegermann, Chem. Phys. Lett. 198, 621 (1992)
${ }^{46} \mathrm{M}$. Beerbom, O. Henrion, A. Klein, T. Mayer, and W. Jaegermann, Electrochim. Acta 45, 4663 (2000).

${ }^{47}$ M. C. Jung, S. R. Raga, and Y. Qi, RSC Adv. 6, 2819 (2016).

${ }^{48}$ J. Kruusma, A. Tõnisoo, R. Pärna, E. Nõmmiste, and E. Lust, Nanomaterials 9 , 304 (2019).

${ }^{49}$ S. Wu et al., Nat. Commun. 10, 1161 (2019).

${ }^{50}$ J. D. McGettrick, K. Hooper, A. Pockett, J. Baker, J. Troughton, M. Carnie, and T. Watson, Mater. Lett. 251, 98 (2019).

${ }^{51}$ A. F. Akbulatov et al., J. Phys. Chem. Lett. 11, 333 (2020)

${ }^{52}$ T. G. Kim, S. W. Seo, H. Kwon, J. Hahn, and J. W. Kim, Phys. Chem. Chem. Phys. 17, 24342 (2015).

${ }^{53}$ A. J. M. Mackus, C. Macisaac, W. H. Kim, and S. F. Bent, J. Chem. Phys. 146, 052802 (2017)

${ }^{54}$ A. R. Head, S. Chaudhary, G. Olivieri, F. Bournel, J. N. Andersen, F. Rochet, J. J. Gallet, and J. Schnadt, J. Phys. Chem. C 120, 243 (2016).

${ }^{\mathbf{5 5}}$ M. J. Wahila et al., Chem. Mater. 28, 4706 (2016).

${ }^{56}$ S. Anuchai, S. Phanichphant, D. Tantraviwat, P. Pluengphon, T. Bovornratanaraks, and B. Inceesungvorn, J. Colloid Interface Sci. 512, 105 (2018)

${ }^{57}$ E. Rucavado et al., J. Phys. Chem. C 122, 17612 (2018).

${ }^{58}$ L. Grzadziel, M. Krzywiecki, A. Szwajca, A. Sarfraz, G. Genchev, and A. Erbe, J. Phys. D Appl. Phys. 51, 315301 (2018).

${ }^{\mathbf{5 9}}$ R. G. Egdell, S. Eriksen, and W. R. Flavellt, Solid State Commun. 60, 835 (1986).

${ }^{60}$ J. Haeberle, S. Machulik, C. Janowitz, R. Manzke, D. Gaspar, P. Barquinha, and D. Schmeisser, J. Appl. Phys. 120, 105101 (2016).

${ }^{61}$ P. A. Cox, R. G. Egdell, C. Harding, W. R. Patterson, and P. J. Tavener, Surf. Sci. 2-3, 179 (1982).

${ }^{62}$ D. F. Cox, T. B. Fryberger, and S. Semancik, Phys. Rev. B 3, 2072 (1988).

${ }^{63}$ J. Oviedo and M. J. Gillan, Surf. Sci. 467, 35 (2000).

${ }^{64}$ I. Manassidis, J. Goniakowski, L. N. Kantorovich, and M. J. Gillan, Surf. Sci. 3, 258 (1995).

${ }^{65}$ P. Nunez et al., J. Phys. Chem. C 123, 20116 (2019).

${ }^{66}$ V. Paunović, M. Rellán-Piñeiro, N. López, and J. Pérez-Ramírez, Catal. Today 10, 6129-6143 (2020).

${ }^{67}$ K. Henkel, C. Das, M. Kot, and D. Schmeisser, J. Vac. Sci. Technol. A 35, $01 \mathrm{~B} 135$ (2017).

${ }^{68}$ C. Das, K. Henkel, M. Tallarida, and D. Schmeisser, J. Vac. Sci. Technol. A 33, 01A144 (2015).

${ }^{69}$ S. Wang, T. Sakurai, W. Wen, and Y. Qi, Adv. Mater. Interfaces 22, 1800260 (2018).

${ }^{70}$ D. Koushik et al., J. Mater. Chem. C 7, 12532 (2019).

${ }^{71}$ L. E. Black and W. M. M. Kessels, Appl. Phys. Lett. 112, 201603 (2018).

${ }^{72}$ L. E. Black and W. M. M. Kessels, Sol. Energy Mater. Sol. Cells 185, 385 (2018).

${ }^{\mathbf{7 3}}$ See supplementary material at https://doi.org/10.1116/6.0000447 for specific details regarding XPS and UPS fitting procedures, ALD processes and PSCs device structure and additional results from ALD and s-ALD regarding XRD, XPS and UPS are shown.

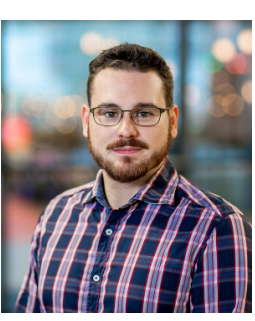

Andrea E. A. Bracesco received his M.Sc. degree in Sustainable Energy Technology from the University of Twente in 2019 . He is currently a Ph.D. student at the Plasma and Materials Processing group in the Department of Applied Physics at the Eindhoven University of Technology. His research is focused on interface engineering by atomic layer deposition in hybrid organometal halide perovskite solar cells. 


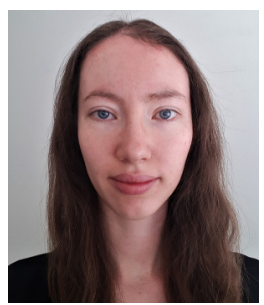

Claire Burgess received her Ph.D. from Imperial College, London, in 2017. She carried out a postdoc at the same institution, before joining Eindhoven University of Technology for her second postdoc position. Her research interests include the growth of thin films, especially by atomic layer deposition, and their characterization and optimization for use in devices.

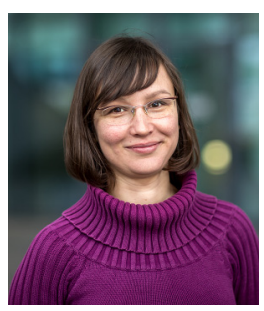

Anna Todinova is a postdoctoral researcher in the Plasma and Materials Processing Group of the Department of Applied Physics at the Eindhoven University of Technology. She holds B.Sc. and M.Sc. degrees in Applied Physics and Mathematics from the Moscow Institute of Physics and Technology (Moscow, Russia) and Ph.D. from the Institute of Biochemical Physics (Russian Academy of Sciences, Moscow, Russia). Her research interests cover the understanding of the electrical properties of metal oxide layers and the keys to efficient performance of metal oxide layers as charge transport layers in perovskite solar cells.

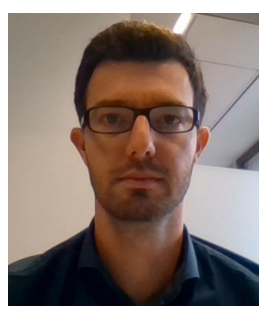

Valerio Zardetto is currently a researcher scientist at Nederlandse Organisatie voor toegepast-natuurwetenschappelijk onderzoek (TNO) in the Netherlands. Previously, he was a postdoc at the Eindhoven University of Technology. His research focuses on the development of thin film solar cell technologies, including perovskite and copper indium gallium selenide (CIGS) solar cells and the development of thin film deposition techniques such as atomic layer deposition.

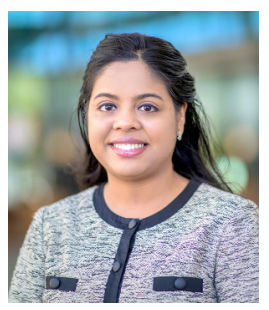

Dibyashree Koushik is a postdoctoral researcher in the Department of Applied Physics at the Eindhoven University of Technology (TU/e). She received her Integrated M.Tech. (gold medalist) in Nanotechnology from the Central University of Jharkhand, India, in 2015. In the same year, she joined the Department of Applied Physics at TU/e to pursue her Ph.D. Her doctoral thesis was focused on designing interfaces in hybrid perovskite solar cells by atomic layer deposition. After earning her Ph.D. in 2019, Dibyashree continued as a postdoctoral researcher. Her current research interests include the development of atomic layer deposited thin films and their interface engineering in single-junction and tandem solar cells.

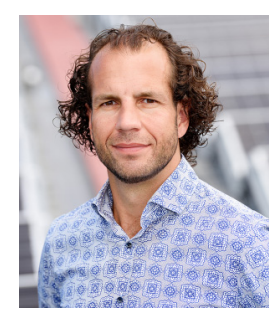

W. M. M. Erwin Kessels is a professor in Applied Physics at the Eindhoven University of Technology where he is also the scientific director of the NanoLab@TU/e clean room facilities. His research interests cover the field of synthesis of ultrathin films and nanostructures using methods such as atomic layer deposition (ALD) and atomic layer etching. Within this field of atomic-scale processing, he has contributed most prominently by his work on plasma-assisted ALD, his research on ALD for photovoltaics, and nanopatterning including area-selective ALD. Erwin is also the driving force behind the AtomicLimits.com blog and the founder of the ALD Academy.

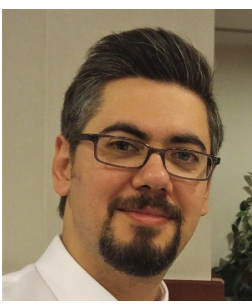

Ilker Dogan received his M.Sc. degree in physics from the Middle East Technical University, Ankara, Turkey, in 2008, and his Ph. D. degree in applied plasma physics from the Eindhoven University of Technology (TU/e), Eindhoven, The Netherlands, in 2014. He currently works at TNO-Solliance and is responsible from the upscaled processing of the perovskite solar cell technology. His expertise includes synthesis and characterization of nanoparticles in plasmas, large area dry and wet chemical coatings, sustainable energy technologies such as lithium-ion batteries and sodium-sulfur batteries, photoelectrocatalytic $\mathrm{CO}_{2}$ conversion, and perovskite solar cells.

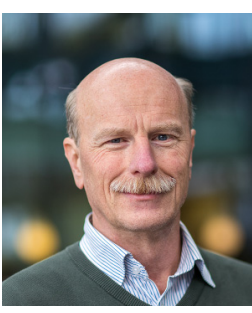

Christ Weijtens received his M.Sc. in Chemistry from the University of Nijmegen in 1982 and his Ph.D. from the Eindhoven University of Technology (TU/e) on ITO and its application in imagers in 1990. In 1982, he joined Philips Research Laboratories in Eindhoven (The Netherlands) and later in Aachen (Germany). He contributed to topics ranging from solid-state image sensors, discharge lamps, cathode ray tubes to OLEDs, and more. In 2016, he moved to the Molecular Materials and Nanosystems group at the TU/e. His present main research focus is on photoelectron spectroscopy on OLED and photovoltaic materials.

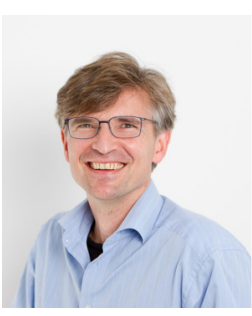

Sjoerd Veenstra is Program Manager at TNO and Solliance. Sjoerd has a passion for PV. He received his Ph.D. from the University of Groningen. Sjoerd stayed at UCSB (intern) and Cornell University (visiting scientist). He started as a researcher working on organic solar cells at the Energy Research Center of the Netherlands (ECN). In 2011, he moved to Eindhoven (NL) to join the thin film PV activities of Solliance and started working on perovskite solar cells at the end of 2014. Since 2018, he works for TNO and leads the perovskite solar cell team. As of 2019 , he is program manager perovskite solar cells of Solliance. 


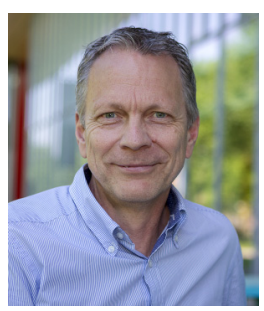

Ronn Andriessen received his Ph.D. in (Photo-)Chemistry in 1991 from the University of Leuven (Belgium). From 1991 to 2008, he was R\&D manager at Agfa-Gevaert for next generation and new functional thin film products. In 2008, Ronn became program manager at the Holst Centre. In 2010, he was involved in the setup of the Solliance R\&D collaboration focusing on thin film PV technologies. He was program manager at Solliance from 2011 till 2016, when he became program director of Solliance. In early 2018, he became director of Solliance. Ronn has contributed to over 100 patent applications and more than 70 scientific publications.

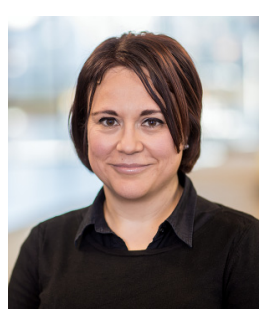

Adriana Creatore is a professor in Applied Physics at the Eindhoven University of Technology (TU/e). She received her M.Sc. (with highest honors) and Ph.D. in Chemical Sciences from the University of Bari (Italy) in 1997 and 2001, respectively. She joined TU/e with a Marie Curie postdoc fellowship (2001-2003), followed by a Veni grant from The Netherlands Organization for Scientific Research (2004-2007). In 2007, she was appointed as assistant professor and Sustainable Energy Technology fellow in solar energy. In 2011, she became associate professor, in parallel with an NWO-Aspasia grant. In 2019, she became full professor. Her research, built upon the knowledge and expertise in plasma physics and chemistry, addresses (plasma-assisted) atomic layer deposition (ALD). Specifically, Adriana focuses on the design and engineering of interfaces and thin films with control at atomic scale for the next generation of energy conversion and storage technologies. Selected examples are metal halide perovskite PV, electro-catalysis, and 3D all-solid-state lithium-ion batteries. Her research outcome in the past five years includes synthesis of efficient and charge selective transport layers $\left(\mathrm{TiO}_{2}\right.$, $\mathrm{SnO}_{2}, \mathrm{NiO}$ ) in metal halide perovskite $\mathrm{PV}$ and tunnel recombination junctions for tandem PV (crystalline silicon/perovskite and CIGSe/perovskite), insights into ALD growth of metal oxides on metal halide perovskite substrates, synthesis of non-noble metal electrocatalysts (such as cobalt phosphate), and gas/surface reaction mechanisms during ALD of Li-containing compounds $\left(\mathrm{Li}_{2} \mathrm{CO}_{3}, \mathrm{LiF}, \mathrm{LiPO} \mathrm{N}, \mathrm{LiAlF}_{4}\right)$. These application areas are investigated in close collaboration with international academic partners, research institutes, and the industry. Adriana has been selected as principle scientist representing the focus area "Chemistry for sustainable energy systems" within the recently founded Eindhoven Institute for Renewable Energy Systems (EIRES). In 2019, Adriana has served the American Vacuum Society (AVS) as Symposium Program Chair (AVS 66) and crafted the following symposium theme: "Shaping our future: Materials, technologies and processes for energy transition." She is currently member of the AVS Board of Directors.

To the 16 years old herself, she would say: "Don't be scared. Do what you would like and like what you do." 